\title{
Quantitative Proteomics of Potato Leaves Infected with Phytophthora infestans Provides Insights into Coordinated and Altered Protein Expression during Early and Late Disease Stages
}

\author{
Chunfang Xiao ${ }^{1,2}$, Jianhua Gao ${ }^{1,2}$, Yuanxue Zhang ${ }^{1,2}$, Zhen Wang ${ }^{1,2}$, Denghong Zhang ${ }^{1,2}$, \\ Qiaoling Chen ${ }^{1,2}$, Xingzhi Ye ${ }^{1,2}$, Yi Xu ${ }^{1,2}$, Guocai Yang ${ }^{1,2}$, Lei Yan ${ }^{1,2}$, Qun Cheng ${ }^{1,2}$, \\ Jiaji Chen ${ }^{1,2}$ and Yanfen Shen ${ }^{1,2, *}$ \\ 1 Southern Potato Research Center of China, Academy of Agricultural Sciences, Enshi 445000, Hubei, China; \\ 15971827976@163.com (C.X.); wend315@126.com (J.G.); 13636289689@163.com (Y.Z.); \\ wangzhen20093332@163.com (Z.W.); zhangdenghong2@126.com (D.Z.); 18627798503@163.com (Q.C.); \\ yxz161718@163.com (X.Y.); enshizizi@126.com (Y.X.); ygcdxs@126.com (G.Y.); 18727670407@163.com (L.Y.); \\ enshicq@126.com (Q.C.); chenjia-ji@163.com (J.C.) \\ 2 Enshi Tujia and Miao Autonomous Prefecture Academy of Agricultural Sciences, Enshi 445000, Hubei, China \\ * Correspondence: 13872728746@163.com
}

Received: 11 November 2018; Accepted: 24 December 2018; Published: 1 January 2019

check for updates

\begin{abstract}
In order to get a better understanding of protein association during Solanum tuberosum (cv. Sarpo Mira)-Phytophthora infestans incompatible interaction, we investigated the proteome dynamics of cv. Sarpo Mira, after foliar application of zoospore suspension from $P$. infestans isolate, at three key time-points: zero hours post inoculation (hpi) (Control), 48 hpi (EI), and 120 hpi (LI); divided into early and late disease stages by the tandem mass tagging (TMT) method. A total of 1229 differentially-expressed proteins (DEPs) were identified in cv. Sarpo Mira in a pairwise comparison of the two disease stages, including commonly shared DEPs, specific DEPs in early and late disease stages, respectively. Over $80 \%$ of the changes in protein abundance were up-regulated in the early stages of infection, whereas more DEPs (61\%) were down-regulated in the later disease stage. Expression patterns, functional category, and enrichment tests highlighted significant coordination and enrichment of cell wall-associated defense response proteins during the early stage of infection. The late stage was characterized by a cellular protein modification process, membrane protein complex formation, and cell death induction. These results, together with phenotypic observations, provide further insight into the molecular mechanism of $P$. infestans resistance in potatos.
\end{abstract}

Keywords: late blight disease; potato proteomics; Phytophthora infestans; Sarpo Mira; early and late disease stages

\section{Introduction}

Potato late blight disease caused by Phytophthora infestans is one of the most critical crop diseases in the world. Late blight was responsible for the European potato famine in the 19th century [1]. It poses a severe threat to potato production worldwide, with estimated annual economic losses of over six billion dollars, mainly due to yield loss and the high cost of fungicide [2]. Management of the late blight disease pathogen is challenged by global warming, environmental regulations against the use of chemical fungicides, and P. infestans remarkable pathogenicity [3].

$P$. infestans shows an initial asymptomatic biotrophic phase of infection followed by a necrotrophic phase. During the biotrophic stage, P. infestans forms appressoria, primary and secondary hyphae, and 
specialized structures called haustoria, through which effectors are delivered into the host apoplast or adjacent cells [4]. Plants have evolved an array of innate immune systems to detect and respond to a wide range of these P. infestans effectors. For example, PTI (Pathogen-associated molecular pattern-triggered immunity), which uses transmembrane pattern recognition receptors (PRRs) that respond to evolving microbial- or pathogen-associated molecular patterns (MAMPS or PAMPs). PRRs include a class of leucine-rich repeat (LRR)-receptor kinases (RK), for example CEBiP [5] and OsCERK1 [6,7] in rice; AtCERK1 [8-11], LYM2 [12-14], RBGP1 [15], and RLP30 [15] in Arabidopsis; and EIX2 [16], Ve1 [17,18], and Cf-9 [15]. However, knowledge about PRRs in the potato host is scarce. PTI has the potential to fend off various microbes, pathogenic or not, due to the conserved nature of PAMPs (e.g., fungal chitin) across species, genera, family, or class. Thus, PRRs can provide resistance to most non-adapted pathogens, as well as contribute to basal immunity during infection or disease process. In response to these PTI defense systems, pathogens that could breach PTI successfully deploy a huge number of effectors to render pathogen virulence. Such effectors change the normal function of PTI, resulting in effector-triggered susceptibility (ETS) [19]. A large number of extracellular and cytoplasmic effectors in the P. infestans genome have been identified and increasing evidence for their role in establishing ETS exists $[20,21]$.

However, to combat pathogens with established ETS, host plants have evolved a race-specific immunity, a well-described host resistance mechanism that is governed by dominant R-genes. Many R-genes have been cloned, and most of them encode proteins with $\mathrm{N}$-terminal nucleotide-binding sites (NBSs) and C-terminal leucine-rich repeats (LRRs). R-genes encode proteins that recognize pathogen effectors to establish effector-triggered immunity (ETI). This recognition triggers a cascade of defense responses, mediated by a complex-signaling network, in which plant hormones, like salicylic acid (SA) and jasmonic acid (JA), play a significant role and the resistance is manifested as a localized hypersensitive cell death response (HR) at the site of infection.

Recently, next-generation sequencing (NGS) technologies are transforming biology research [22,23]. Genome sequences of potato and P. infestans have been published [2,24], making sequencing-based "omics" studies more accessible to potato late blight researchers. Proteomics has become a viable alternative for molecular analysis, providing information and tools for a better understanding of the plant-pathogen relationship. Recently, proteomics has dramatically evolved in the pursuit of large-scale functional assignment of candidate proteins and, by using this approach, several proteins expressed during potato-P. infestans interaction have been identified [25-27]. Two-dimensional electrophoresis (2-DE) based proteomics [25], gel-based protein shotgun mass spectrometer [28], and, most recently, label-free proteomics analysis [26,27], have shed light on our understanding of compatible and incompatible interactions between $P$. infestans and potato.

The recently developed isobaric label proteomics, such as isobaric tags for relative and absolute quantification (ITRAQ) [29] and tandem mass tags (TMT) [30], are chemically conjugated to the primary amines of peptides after tryptic digestion and are compatible with samples from multiple sources [29]. Therefore, in this study, we used the TMT method to measure and compare the changes in protein abundance of potato cv. Sarpo Mira after foliar application of zoospore suspension of P. infestans at three key timepoints, covering potato-P. infestans oomycete early (EI) and late (LI) stage of interaction. A total of 1229 differentially-expressed proteins (DEP) were identified, 75 DEPs at the early stage and 723 DEPs at the late stage of the disease process. The proteins identified at the early and late stage could play an essential role in early pathogen recognition, signal transduction, disease resistance processes against $P$. infestans, and possibly disease pathogenesis. This study will contribute to a better understanding of the molecular mechanism of $P$. infestans interaction with potato. 


\section{Results and Discussion}

\subsection{Subsection Phenotypic Differences between the Three Stages of Disease Conditions}

A time series assessment of Sarpo Mira leaf phenotype challenged with P. infestans is shown in Figure 1a,b. Three replicates were used for each treatment in these tests. After spraying the whole potato plant with $P$. infestans zoospores, there was no observable microscopic hypersensitive reaction (HR) lesions at 0 Hours post inoculation hpi (Control); however, by 48 hpi (EI), HR lesions had appeared, which resulted in a localized necrosis that resembled a $P$. infestans-induced hypersensitive response, and at $120 \mathrm{hpi}$ (LI) the leaves had developed much larger $\mathrm{H}$-induced necrosis, consistent with a typical R gene-mediated HR lesions expansion, as previously reported in Sarpo Mira [31]. There was a significant difference in the lesion size of LI relative to EI, as seen in (Figure 1b), and consistent with previous studies [32,33]. Based on these results, we designated the interval between time-points Control and EI as early disease stage and timepoint EI to LI as late disease stage.

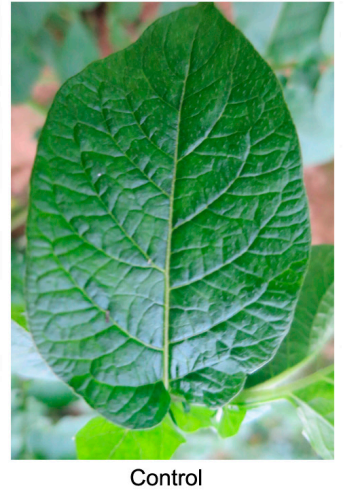

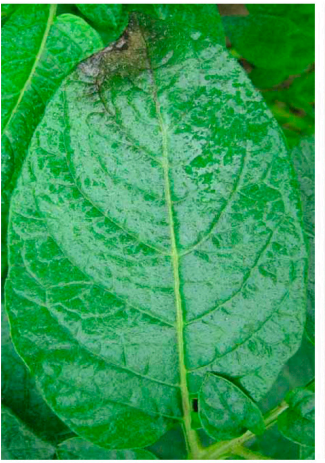

EI

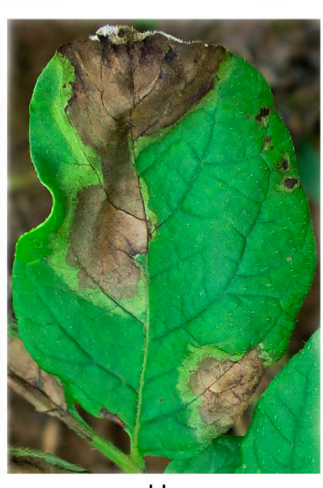

LI

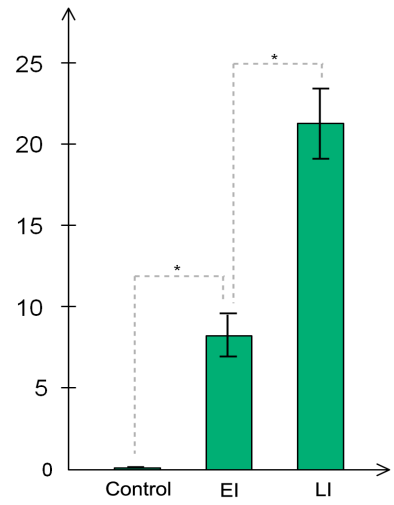

(b)

(a)

Figure 1. Phenotypic observation of the three time-points. Control corresponds to time-point 0 Hours post inoculation, EI corresponds to $48 \mathrm{hpi}$, and LI corresponds to $120 \mathrm{hpi}$. (a) Sizes of lesions induced by the P. infestans zoospores at different exposure times. The diameter of each lesion was measured at 2 and 5 days after inoculation (b). Three replicates were used for each treatment in these tests. Bars represent the standard deviation of three replicates. Statistical significance was analyzed using Student's $t$-test. The asterisk indicates the significant difference $\left({ }^{*} p<0.05\right)$.

\subsection{Overview of Protein Expression in Potato Leaves Challenged with P. infestans Oomycete}

Potato cv. Sarpo Mira was previously reported to have incompatible interaction with P. infestans [29]; however, systematic analysis of protein association during Sarpo Mira-P. infestans interaction, and their resultant changes in abundance leading to incompatibility, are incompletely understood. Therefore, to shed more light on the changes in protein abundance during the early and late stages of late blight disease, we performed a comparative proteome survey by TMT method [29] at three key time-points (Control, EI, and LI time-points. See method section) on leaves of potato clone Sarpo Mira inoculated with $P$. infestans oomycete. Three biological replicates were collected at the same time. With these measurements, a total of 15,813 high-quality peptides (in at least two replicates per time-point) corresponding to 4643 proteins were identified in the time series analysis (Table S1). Of the 4643 proteins, 1229 (at least one unique peptides) were found to be differentially expressed proteins (DEP) in a pairwise comparison between the time-points. Among the 1229 DEPs, 952 had functional annotations (Table S2). In all, a total of 1082 DEP could be classified into 70 different significantly-enriched protein domains and features by InterProScan analysis, 21 PFAM protein domains, and 56 significantly-enriched Kyoto Encyclopedia of Genes and Genomes pathways (Table S2) [34]. The total number of DEPs observed in each pairwise comparison is shown in Figure 2a 
and Tables S3-S5. For example, 1022 DEPs were observed in the group pair of H/L, covering the whole-time course. The pair of EI/Control had 75 proteins representing DEPs in the early stage of pathogen invasion, and LI/EI had 723 DEPs active during the late stage of the disease process.

Large scale comparative quantitative proteomic studies produce numerous lists of proteins containing biological identifiers, and often it is useful to highlight the overlapping sets between groups of biological data, enabling quick and easy observation of the similarities and differences between the data sets. In this study, dataset overlap between the early and late stage revealed about $2.3 \%$ $(18 / 780)$ of the DEPs were commonly-shared induced proteins throughout the time course (Figure 2b), suggesting that these proteins could be necessary for the sustained HR phenotype observed in the later stages of the disease condition. More strikingly, $90.4 \%$ (705/780) of DEPs were specific to LI/EI, while $7.3 \%(57 / 780)$ was unique to EI/Control (Figure $2 b)$.

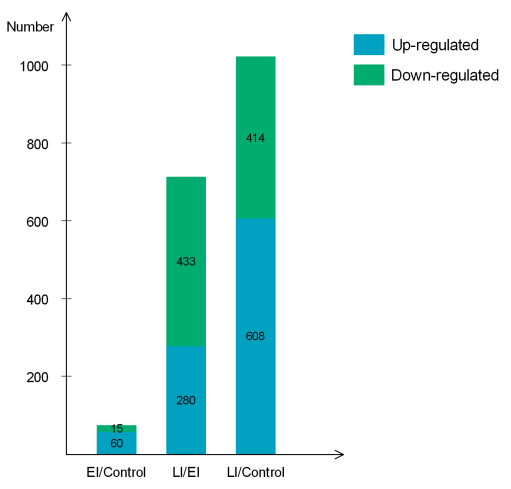

(a)

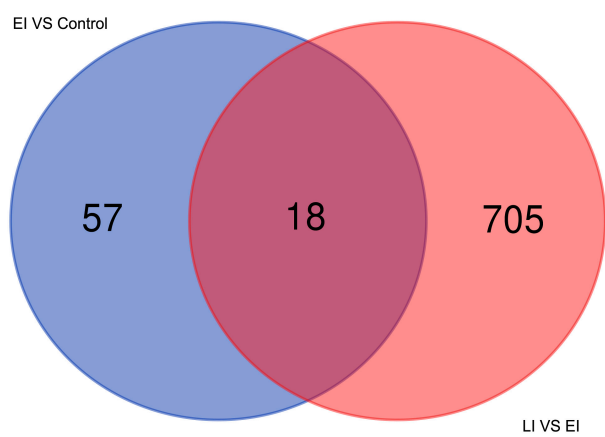

(b)

Figure 2. Differentially expressed proteins between the early and late stage (a). Bar chart showing the number of up- and down-regulated proteins in each of the pairwise comparisons: EI/Control, LI/EI, and LI/Control. green color indicates down-regulated proteins and blue color indicates up-regulated proteins. Overlaps among differentially expressed proteins (DEPs) between the early and late stage (b). Venn diagrams depict overlap of DEPs from each pairwise comparison between the timepoints, EI/Control (early) and LI/EI (late).

\subsection{Gene Ontology Classification of Differentially Expressed Proteins}

Gene ontology classification and KEGG (Kyoto Encyclopedia of Genes and Genomes) analysis was used to reveal the implication of all DEPs identified in this study (Figure 3a). Gene Ontology analysis showed that much more biological process categories were highly abundant in the DEPs. The protein classes "Metabolic processes" (41.3\%), "Cellular processes" (32\%), and "Response to stimulus" (6.1\%) were the most abundant categories (Figure 3a). The label "Metabolic process" covers several sub-biological process categories; notable among them were primary and secondary metabolism, such as carbohydrate, lipid, protein, amino acid, and nucloeobase-containing compound metabolism. Also, within this category are systemic-acquired resistance and defense response to fungus. The proteins involved in this group were mostly up-regulated in the early disease stage. The "Cellular processes" includes protein folding, microtubule-based process, signal transduction, cell death, protein secretion cellular homeostasis, and oxidant detoxification. "Response to stimulus" covered response to stress, response to biotic and abiotic stimulus, response to endogenous stimulus, and response to chemical. Several of these proteins encoded peroxidase, pectinesterase, and endochitinase-like compounds, and were also up-regulated in both disease stages (Figure 3a and Table S6).

Molecular function classification highlighted over-representation of "Catalytic Activity" (45\%) and "Binding" (40\%) as the major function of the DEPs. The "Catalytic Activity" heading included oxidoreductase activity, transferase activity, hydrolase activity, lyase activity, isomerase activity, and ligase activity. The "Binding" category encompassed protein binding, protein-containing complex binding, ion binding, drug and cofactor binding, iron-sulfur cluster binding, heterocyclic 
compound binding, glutathione binding, and carbohydrate derivative binding (Figure 3a and Table S6). The majority of the proteins in this category were uncharacterized. Other molecular function categories worthy of mention include antioxidant activity, enzyme regulator activity, and nuclear import signal receptor activity. About half of the DEPs were in the cellular component, of which the majority were in the "Cell" $(24.10 \%)$, which included the extracellular region and apoplast. "Cell part" (23.96\%), covering intracellular plasma membrane and chloroplast envelope; "Organelle" (17.65\%), covering organelle membrane, intracellular organelle, and organelle lumen; "Protein complex" $(11.68 \%)$, including THO complex, U1 snRNP, nucleosome, transcription factor complex, chloroplastic endopeptidase Clp complex, and eukaryotic translation elongation factor 1 complex; "Membrane" $(8.39 \%)$ and "Membrane part" (5.28\%), which encompasses membrane protein complex and inner mitochondrial membrane protein complex (Figure 3a and Table S6).

A functional enrichment test was used to identify over-represented proteins that may have an association with early and late disease phenotypes, by interrogating the data for the GO enrichment of protein sets. The KEGG database was used to determine significantly enriched pathways in the early or late disease stage (Table S6).

In the early disease stage, the GO enrichment test revealed response to stimulus and detoxification as the most significantly-enriched biological processes (Figure 3b). The significantly-enriched molecular functions were antioxidant activity and catalytic activity, which included peroxidase activity (Figure 3b), while several of these enriched proteins were located within the extracellular region of the cellular component (Table S6). Considering the late disease stage, we observed that metabolic process and single-organism process were highly significantly-enriched biological processes (Figure 3c). Other enriched biological processes included detoxification, cellular component and biogenesis, and positive regulation of biological processes (Table S6). Enriched molecular functions included structural molecular activity, antioxidant activity, and catalytic activity (Figure 3c). In the cellular component, we noticed overrepresentation of proteins in the cell, cell part, organelle, and organelle part (Figure 3c).

Pathway coverage analysis using the KEGG database found that the phenylpropanoid biosynthetic pathway was the most significantly-enriched in the early disease stage (Figure 3d); most of these proteins encoded peroxidase/peroxidase-like and hydroxycinnamyl proteins. Other enriched pathways included fatty acid metabolism and biosynthesis of unsaturated fatty acid (Figure 3d). As reported by others, the phenylpropanoid pathway is essential to plants because of its role in the production of the hydroxycinnamyl alcohols, which serve as the building blocks of lignin, and confers structural support, vascular integrity, and pathogen resistance to plants [35]. Additionally, high induction of several genes mapped to the phenylpropanoid pathway has been reported following $P$. infestans invasion [36]. Meanwhile, biosynthesis of secondary metabolism, ribosome, glutathione metabolism, biosynthesis of amino acid, porphyrin and chlorophyll metabolism, ribosome biogenesis, valine, leucine and isoleucine degradation, synthesis and degradation of ketone bodies, and fatty acid metabolic pathways were identified as the most significantly-enriched pathways in the late disease stage (Figure 3d). Together these results suggested that the identified proteins represent a functionally-active subset of the entire proteome associated with the potato response to P. infestans oomycete infection. 


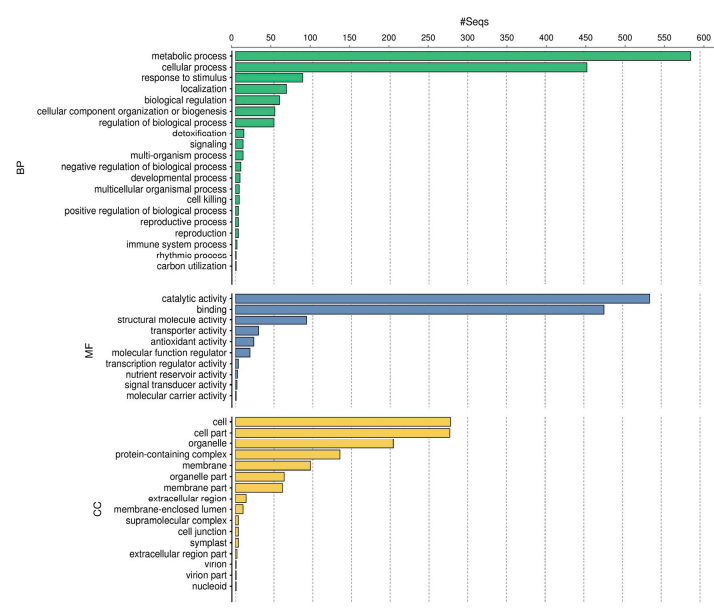

(a)
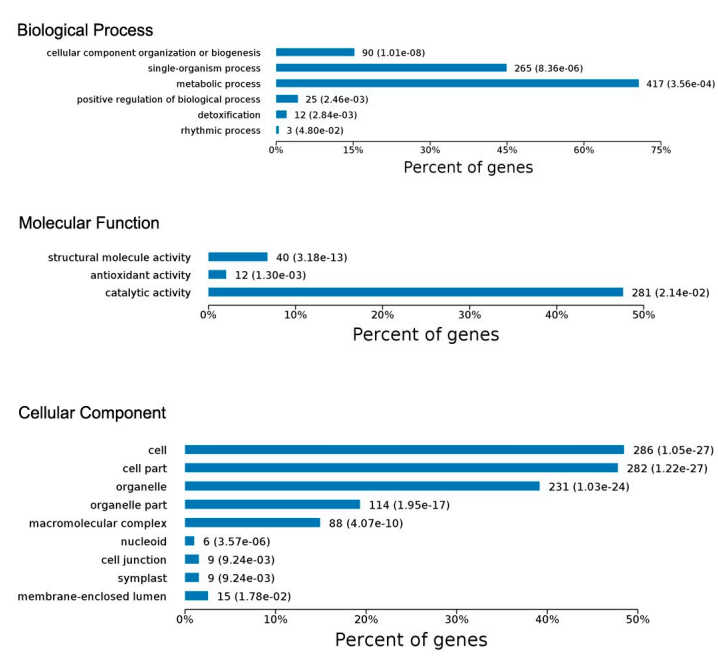

(c)

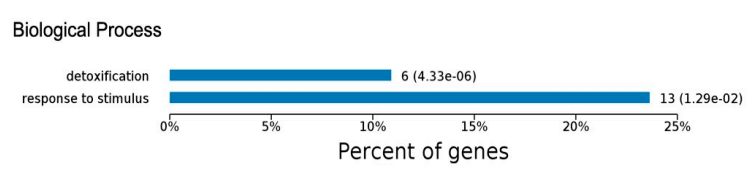

Molecular Function
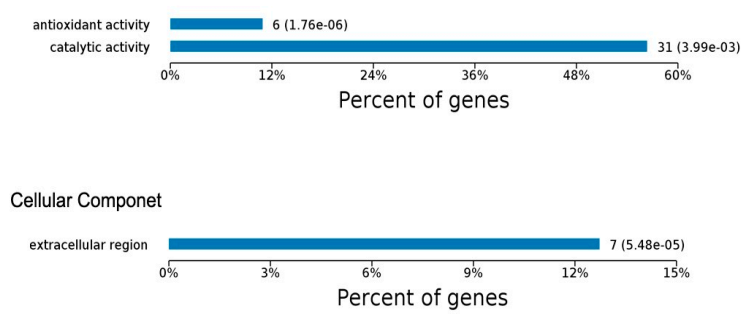

(b)
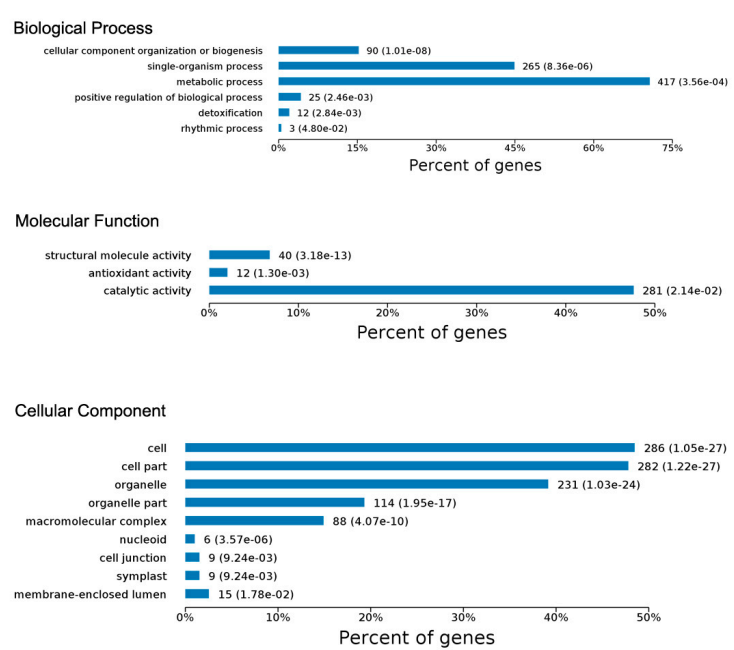

(d)

Figure 3. (a) Gene Ontology functional classification of all DEPs; bar chart shows the distribution of differentially-expressed proteins among the GO biological process (BP), molecular function (MF), and cellular component (CC). (b) GO-based functional enrichment analysis of DEPs at early disease stage. (c) GO-based functional enrichment analysis of DEPs at late disease stage. (d) Kyoto Encyclopedia of Genes and Genomes pathway enrichment of DEPs at the early and late disease stages.

\subsection{Differential Expression Pattern of Proteins Involved at the Early and Late Disease Stages}

To better understand potato- $P$. infestans interaction, it is important to distinguish the potato's specific response to the invading pathogen and protein signatures at various stages of the disease process, which can help shed light on the pathogenic life style, whether in biotrophic relationships (in which the pathogen feeds from living host cells) to necrotrophic associations (in which the microbe feeds on nutrients released from killed cells [37]). Therefore, we examined the expression pattern of proteins involved at the early and late disease stages.

\subsubsection{Early Disease Stage Response Proteins}

As stated earlier, 75 proteins showed a significant difference in protein abundance at the early stage of the disease process (EI/Control-compared proteins, Table S3), of which 60 DEPs were up-regulated, and 15 DEPs were down-regulated (Figure 2a); their expression profile is shown in (Figure 4). GO enrichment test results (False Discovery Rate $<0.05, p<0.01$ ) revealed these proteins were mostly related to detoxification and response to a stimulus, which covers stress response, defense response, 
oxidative burst, and cellular catabolic process (Figure 3b). Further analysis uncovered enriched proteins were most active in the apoplast, cell wall, cell periphery, and external encapsulating structure during pathogen invasion (Table S6). To elucidate cv. Sarpo Mira response to P. infestans at the initial stages of infection, we further examined the expression pattern and the role of DEPs in EI/Control comparison (Table S3). We found a general trend among the DEPs in EI/Control comparison, here most of the proteins significantly increased in abundance from timepoint L to M (Figure 4). Also, we noticed specific enrichment of positively regulated (from time-point Control to EI) functional categories related to defense and oxidative stress response. The most prominent early response proteins present in this group were cell wall degrading enzymes, for example, wall-associated kinase, annexin, osmotins, osmotin-like proteins, serine protease, and proteinase inhibitors, pectinesterase and putative endochitinase; the later are cell-wall degrading enzymes (CWDEs). We also observed five highly up-regulated peroxidase proteins involved in the reactive oxygen species (ROS) metabolic process. The rapid production of reactive oxygen species (ROS) upon pathogen attack has been associated to the defense mechanism for microbial killing and early initiation of host defense responses in plants [38]. In the present study, the up-regulation of these five peroxidase proteins suggests the induction of oxidative burst, which is typically associated with PTI and HR-specific induced cell death, which is consistent with the phenotypic observation (Figure 1a) and previous studies [33].

We also noticed other proteins, including the specific up-regulation of glucan endo-1,3-beta-glucosidase and serine carboxypeptidase-like-33. In this regard, it is well known that extracellular enzymes of plant pathogenic fungi (e.g., glucanases) may have a diversity of roles in host invasion and pathogenesis, either as an inducer or suppressor [39]. Indeed, there are reports that cell walls of oomycetes consist mainly of (1/3)-b-D-glucans, (1/6)-b-D-glucans, and cellulose, which might be required for normal appressorium formation and successful infection of the potato [39]. However, the specific up-regulation of glucan endo-1,3-beta-glucosidase suggests that it either played a significant role in facilitating $P$. infestans penetration of the host cell wall, or the destruction of papillae, blocking the invading pathogen by releasing glucans from the host wall polymers or by hydrolyzing biologically-active glucans, which could act as elicitor. In contrast it may digest wall components of the invading fungal pathogen [40]. Serine carboxypeptidase belonged to a large family of hydrolyzing enzymes, which are believed to play roles in processing and degradation of proteins/peptides, and studies have shown that this protein family are typically up-regulated during pathogen invasion [39]. In the current study, it may be part of the fungal mechanisms of efficient protein digestion during invasion or a past host cell proteolytic machinery against $P$. infestans $[41,42]$. Additionally, we identified another set of DEPs that showed significant up-regulation at the early stage, whose domains possess a binding function possibly involved in the production of antimicrobial compounds. They include the pathogenesis-related protein PR-10 family and the NtPRp27-like protein, which suggests a distinct counter-defense mechanism because most PR proteins are reported to exhibit direct antimicrobial activities and may play a role in both constitutive and induced basal defense responses [43].

Contrastingly, few DEPs were repressed at this stage; notable among them are significantly down-regulated proteins such as dehydrin, pyruvate dehydrogenase, light-inducible tissue-specific protein, and three uncharacterized proteins, M0ZKB0, M1AM40, and M1BUI4 (Table S3). These proteins have functions related to amino acid metabolism and transport, sterol biosynthesis, and abscisic acid signaling. To put these results into perspective, the increased abundance of the majority (60/75) of DEPs in EI/Control indicated an early activation of cell wall-associated defense proteins involved in signal transduction, deployment of basal resistance, and initiation of $\mathrm{R}$ gene-mediated resistance processes, which reflects a coordinated activation and repression of specific cell wall-associated proteins to correlate with the precise cellular defense requirement to restrict $P$. infestans invasion. 


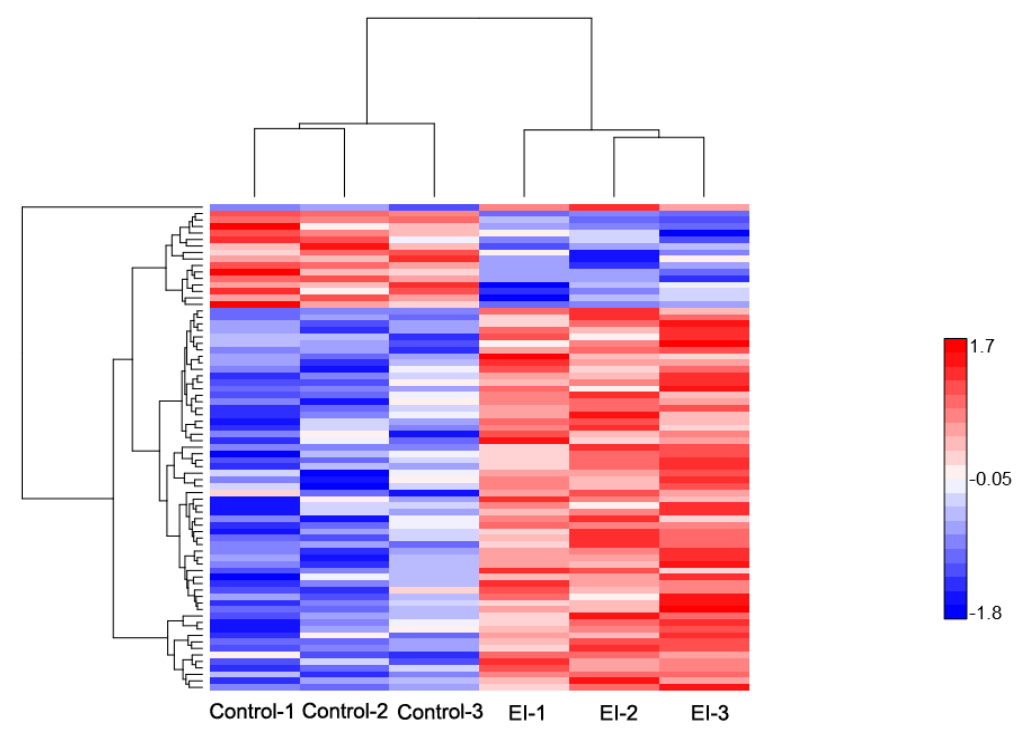

Figure 4. Hierarchical clustering of differentially-expressed proteins at the early disease stage. Heat map showing the changes in protein expression: Proteins with high expression levels (red); proteins with low expression level (blue).

\subsubsection{Late Disease Stage Response Proteins}

The profile of the 723 DEPs identified during the late stage is reported in Figure 5. Within this group, a total of 280 DEPs were up-regulated and 443 were significantly down-regulated, as shown in Figure 2a and Table S4. Functional enrichment showed that the majority of the proteins were involved in cellular component organization, metabolic process, and single-organism process, which encompasses cellular protein modification process and membrane protein complex formation (Figure $3 \mathrm{c}$ and Table S6). We noticed a consecutive up-regulation of several proteins with the binding function, including the resistance (R) gene product containing CC-NB-ARC and LRR domains, as well as chitin-binding domains. Typically, $\mathrm{R}$ proteins are conserved across the plant kingdom, and have been shown to mediate the resistances of race-specific diseases in plants by recognizing effectors and initiating effector triggered immunity (ETI) [20,21,38]. Several other proteins that were significantly up-regulated were identified within this group, which included proteins possessing acid phosphatase-class B domain, osmotin/thaumatin-like domain, endochitinase activity, and kunitz proteinase inhibitor. The latter is a part of potato proteolytic enzyme inhibitors, which may play an important role in the natural defense mechanisms of the potato plant against phytopathogen attack $[27,44]$ In addition to the above were hyoscyamine-beta-hydroxylase (H6H), Puroindoline-A (PIN-A), Puroindoline-I (PIN-I), lipoxygenase, and hydroxy-methylglutaryl coenzyme A reductase (HMGR). H6H is an enzyme belonging to the family of oxidoreductases, and the last rate-limiting enzyme directly catalyzing the formation of scopolamine in the tropane alkaloids (TAs) biosynthesis pathway [45]. Earlier studies have shown that $\mathrm{H6H}$ was concurrently significantly up-regulated, among other $\mathrm{R}$ gene proteins, following $P$. infestans treatment in resistant potato cultivars relative to susceptible genotypes [46]. PIN-A and PIN-I are transmembrane proteins involved in auxin efflux [47]; their specific role in potato-P. infestans interaction is not clear. Similarly, HMGR is known to be strongly induced by fungal elicitors in rice [45]. In the present study, and generally, it is likely that these proteins together might play a role in the production of highly complex toxic anti-microbial or anti-fungal compounds as defense against invading pathogens [46].

To survive in a peroxidative environment, microbes produce natural antioxidants within host cells, or modulate host cells to produce protectants, including vitamin C, glutathione (GSH) carotenoids, reductases, peroxidases, and several others $[48,49]$. Here, we identified proteins that are possibly associated with these processes mentioned above and may be implicated in the expansion of late-stage 
disease processes. These included: peroxidase family proteins and threonine dehydratase, an enzyme involved in isoleucine biosynthesis by catalyzing the deamination of threonine. It was reported to have similar function to serine-threonine dehydratase, a versatile catalyst that functions as a coenzyme in a multitude of reactions, including amino-sugar breakdown [50]. Others were: sucrose synthase, formate dehydrogenase, biotin, and lipoic acid-binding proteins, which may serve as sources of energy for the pathogen. Additional up-regulated proteins were serine-threonine kinases, possibly $P$. infestans secreted kinases [51]. Calcium-dependent protein kinase, arginine N-methyltransferase (their function in the late stage disease process is unknown) and Tyrosine Phosphatase (reported in bacteria is an effector protein), when overexpressed, significantly increases bacterium Pseudomonas syringae virulence [52,53].

Several studies have reported that genes encoding hydrolytic enzymes, such as serine protease, glucosidases, glucanases, and lyases, constituted a major portion of Phytophthora potential pathogenicity factors [48]. Among the significantly induced pathogenesis factors were enzymes: beta-glucanase, glycosyl hydrolases, cysteine protease, and pectate lyase. We also noticed ATP synthase and proton ATPase transmembrane transporter; their specific role in pathogenesis is unknown.

Notable significantly down-regulated proteins were those involved in the structural integrity of the ribosome, such as ribosome recycling factor domain proteins, $60 \mathrm{~S}$ ribosomal protein L18a, acidic ribosomal protein P1a-like, 50S ribosomal protein L32, and ribosomal-L12 proteins. We noticed other proteins with catalytic and binding domain functions, such as cellulose synthase, histone H2A, Nicotinamide adenine dinucleotide phosphate (NADPH)-protochlorophyllide oxidoreductase, pectinesterase, endoglucanase, FK506-binding protein, and PPM-type phosphatase domain. The latter being dephosphorylate serine and threonine residues. Among the down-regulated proteins were also: thioredoxin-like protein CITRX a chloroplastic protein, demonstrated to be involved in the negative regulation of cell death and tomato Cf-9 resistance protein function by specifically interacting with Cf-9 [54]. Silencing of CITRX accelerated the Cf-9/Avr9-triggered hypersensitive response in both tomato and Nicotiana benthamiana, together with the enhanced high accumulation of reactive oxygen species, and the induction of down-stream defense-related genes. In the same study, silencing of CITRX also conferred increased resistance to the fungal pathogen Cladosporium fulvum in susceptible Cf0 tomato [54,55]. Several uncharacterized proteins with acetyltransferase-like domain proteins, including M1BC65, a member of the chloramphenicol acetyltransferase-like domain superfamily, was also identified. In addition to enzyme inhibitor and peptide regulator proteins, such as Clone PI9149 apoptosis inhibitor 5-like protein and Proteinase inhibitor I, the high number of down-regulated DEPs $(443 / 723)$ among the proteins in the LI/EI seems consistent with a shut-down of the cellular metabolic process caused by HR induced necrosis. Collectively, the cellular metabolic process, protein folding, and modification processes, including cell wall re-organization, seem to be the most common roles of the LI/EI-DEPs; therefore, we speculate that these proteins play an essential role in the biological processes possibly involved in disease conditioning and the shut-down of cell metabolic processes at the late infection stage, which are geared towards containment of the invading pathogen. 


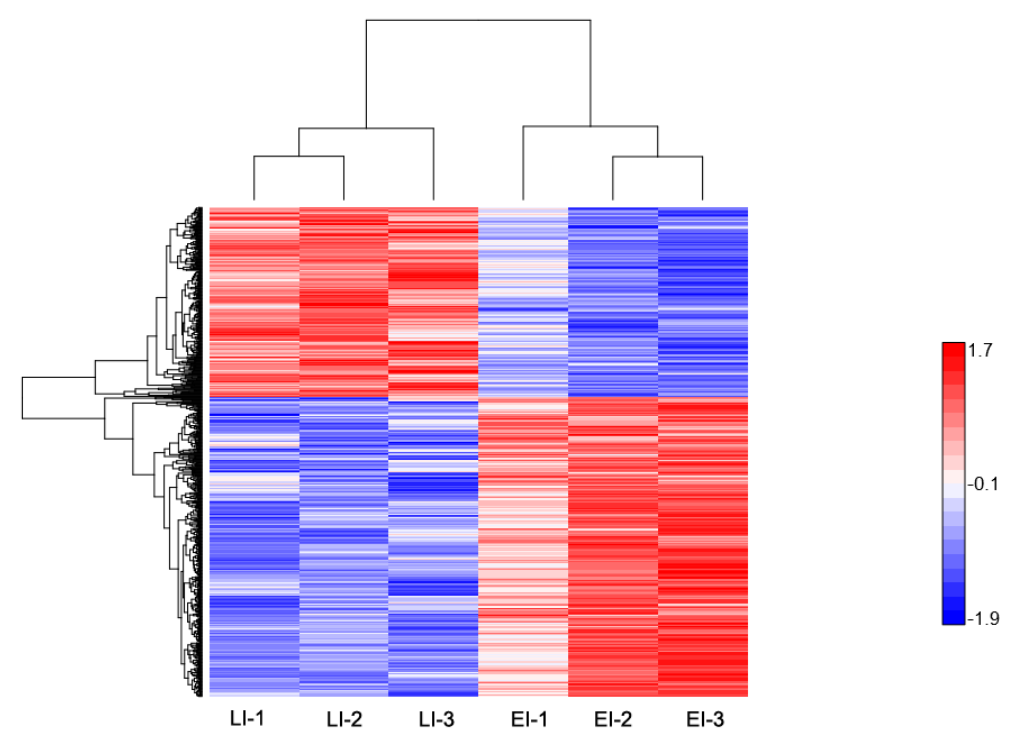

Figure 5. Hierarchical clustering of differentially-expressed proteins at the late disease stage. Heat map showing the changes in protein expression: proteins with high expression levels (red); proteins with low expression level (blue).

2.4.3. Differential Regulation of Commonly Shared Proteins in Response to P. infestans during Early and Late Disease Stages

Our comparative analysis identified 18 proteins shared between the EI/Control comparison and LI/EI comparison (Figure 2b, Table S7). We reasoned that these common set of proteins might respond to the same signal that controls the switch from general plant defense induction, based on PAMPs (PTI), to effector-triggered immunity (ETI), and might have a similar pattern of expression. Indeed, 10 out of the 18 common DEPs showed a similar expression profile throughout the time course. For instance, they were up-regulated explicitly from Control to EI and reached their maximum expression level by time-point LI. Based on GO analysis, these 10 proteins were mostly located within the extracellular region, cell membrane, and protein-containing complexes, and are involved in energy production, vesicle-mediated transport, and response to oxidative stress. From this group we noticed two uncharacterized proteins, M0ZTQ4 (FC = 2.40) and M1CUM0 (FC = 5.6), with at least two- and five-fold increase in abundance. The MOZTQ4 contained the osmotin/thaumatin-like domain, and osmotins are members of pathogenesis-related proteins, secreted into the cell wall to promote basal resistance responses [56]. Whereas M1CUM0 has a domain function related to terpene biosynthesis, a part of antifungal phytoalexins shown to limit the growth hypha during pathogen invasion $[57,58]$.

Remarkably, six out of the remaining eight DEPs (M1ABL9, M1D1L9, M1A3A0, M1A4R1, M1C8Q0, M0ZZ55) showed a dynamic reprogramming in response to $P$. infestans. It is noteworthy that after inoculation these proteins were up-regulated from timepoint Control to EI and reached their highest expression level at time-point EI, afterward they were significantly repressed (Table S7). Further analysis showed that they contained vacuolar protein sorting-associated VPS4 binding domain, ribosomal protein L24 binding domain, pentatricopeptide repeats, histone H1/H5 globular binding domain, 26S proteasome subunit RPN7 domain, and vesicle transport protein, respectively. Generally, plants activate numerous defense mechanisms that can contribute to resistance against pathogen invasion. Considering that a significant increase in lesions' size was observed on the leaves of cv. Sarpo Mira at the LI time-point, compared to the EI timepoint, it follows that the dynamic reprogramming of these proteins might be very significant. This highlights the tight regulation of defense activities within the host cell and demonstrates the urgency for cell wall modification and reinforcement, as well as an efficient transport mechanism for defense-related compounds upon pathogen invasion consistent with the incompatible pathogen-host interaction and observed phenotype in Figure 1a,b. 
Contrastingly, two DEPs, K7WNX1 and M1C639, were consecutively down-regulated throughout the whole-time course; K7WNX1 is a light-inducible tissue-specific ST-LS1 protein and M1C639 contained the transmembrane helix domain. Their role in potato-P. infestans interaction is unknown.

\subsection{Validation of Differentially-Expressed Proteins in Early and Late Disease Stages}

To validate DEPs from the time series proteomics experiments, a total of seven proteins were selected, of which four were randomly selected from the early disease stage and the remaining three were selected from late stage, to verify the expression level, via western blot analysis (Figure 6). Osmotin (fold change $=1.62, p=0.00471$ ), pectinesterase (fold change $=2.53, p=0.0083$ ), endochitinase (fold change $=1.94, p=0.0453$ ), and annexin (fold change $=2.37, p=0.0264$ ) were significantly up-regulated in EI relative to the Control (Figure 6(A1)-(A4)). In the late stage, peptidyl-prolyl cis-trans isomerase (fold change $=1.74, p=0.0051$ ) and type I serine protease inhibitor (fold change $=$ $2.63, p=0.0382$ ) were significantly increased in LI relative to EI (B1, B3). In contrast, photosystem I assembly protein Ycf4 (fold change $=-1.67, p=0.0036$ ) was significantly down-regulated relative to EI (Figure 6(B2)). Potato actin represented loading control. The western blot results were consistent with the times series proteomics data, which strongly support the reliability of the results reported in this paper.

A

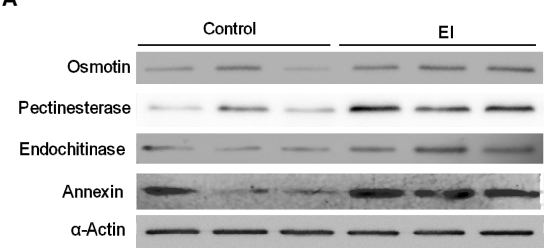

A1

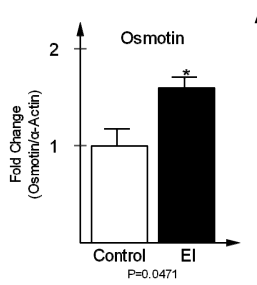

A3

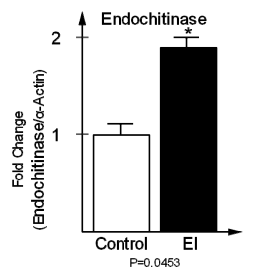

A2

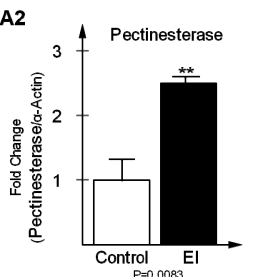

A4

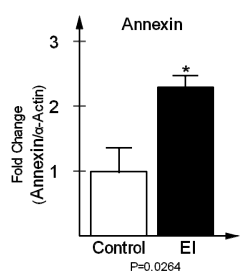

B

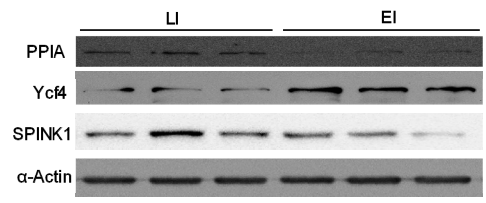

B1

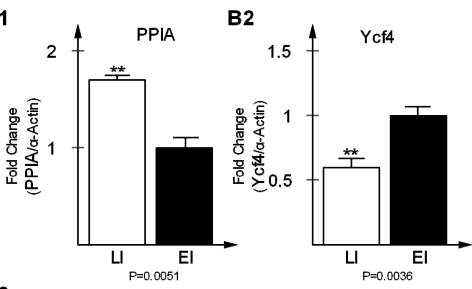

B3

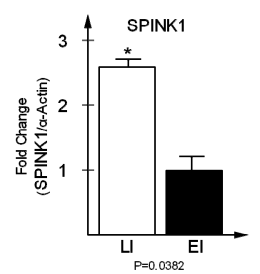

Figure 6. Western blot analysis of differentially expressed proteins at early disease stage (A) and late disease stage $(\mathbf{B})$. Expression levels of Osmotin (fold change $=1.62, p=0.00471$ ), Pectinesterase (fold change $=2.53, p=0.0083$ ), Endochitinase (fold change $=1.94, p=0.0453$ ) and Annexin (fold change $=2.37, p=0.0264)$ were significantly increased in EI relative to Control (A1, $A 2, A 3, A 4)$; PPIA (fold change $=1.74, p=0.0051$ ) and SPINK1 (fold change $=2.63, p=0.0382$ ) were significantly increased in LI relative to $\mathrm{EI}(B 1, B 3)$; Ycf4 (fold change $=-1.67, p=0.0036$ ) was significantly decreased in LI relative to EI and (B2). Potato actin represented loading control.

\subsection{Essential Proteins for Early and Late Disease Stages}

In this study, we systematically identified several proteins that are important for the potato defense response against $P$. infestans at the early and late stages of infection, including those which may otherwise contribute to pathogenesis. The criteria described in the Methods allowed us to select 
several proteins that play a significant role in both disease stages, which are listed in Table 1 and some of which are described hereafter.

Table 1. Proposed candidate proteins that played an essential role at the early and late disease stages.

\begin{tabular}{|c|c|c|c|c|}
\hline Accession & Description & $\begin{array}{c}\text { Fold } \\
\text { Change }\end{array}$ & $p$ Value & GO Names \\
\hline \multicolumn{5}{|c|}{ Early stage up-regulated proteins } \\
\hline M0ZMK7 & $\begin{array}{l}\text { Uncharacterized protein with domain } \\
\text { named as Bet v } 1 \text {. Bet } \mathrm{v} 1 \text { belongs to } \\
\text { family } 10 \text { of plant } \\
\text { pathogenesis-related proteins (PR-10) }\end{array}$ & 1.51 & 0.004 & $\begin{array}{l}\text { P: defense response; } \\
\text { P: response to biotic stimulus }\end{array}$ \\
\hline P52402 & $\begin{array}{l}\text { Glucan endo-1,3-beta-glucosidase, } \\
\text { basic isoform } 3 \text { (Fragment) }\end{array}$ & 1.45 & 0.03 & $\begin{array}{l}\text { F: hydrolase activity, hydrolyzing O-glycosyl } \\
\text { compounds; } \\
\text { P: carbohydrate metabolic process }\end{array}$ \\
\hline M1D1L9 & $\begin{array}{l}\text { Uncharacterized protein containing } \\
\text { domain } 2 \text { of Ribosomal protein L2, }\end{array}$ & 1.36 & 0.02 & $\begin{array}{l}\text { F: structural constituent of ribosome; } \\
\text { C: ribosome; } \\
\text { P: translation }\end{array}$ \\
\hline M1CUM0 & $\begin{array}{l}\text { Uncharacterized protein containing a } \\
\text { domain found in the isoprenoid } \\
\text { synthase family }\end{array}$ & 1.34 & 0.04 & $\begin{array}{l}\text { F: magnesium ion binding; } \\
\text { P: metabolic process; } \\
\text { F: terpene synthase activity }\end{array}$ \\
\hline M1D578 & Peroxidase & 1.34 & 0.04 & $\begin{array}{l}\text { F: peroxidase activity; } \\
\text { P: response to oxidative stress; } \\
\text { F: heme binding; } \\
\text { P: hydrogen peroxide catabolic process; } \\
\text { P: oxidation-reduction process }\end{array}$ \\
\hline M1A3A0 & $\begin{array}{l}\text { Uncharacterized protein containing } \\
\text { Pentatricopeptide repeat (PPR) }\end{array}$ & 1.29 & 0.02 & F: protein binding \\
\hline M1A035 & Carboxypeptidase & 1.28 & 0.03 & $\begin{array}{l}\text { F: serine-type carboxypeptidase activity; } \\
\text { P: proteolysis }\end{array}$ \\
\hline M1D051 & Wall-associated kinase & 1.28 & 0.03 & $\begin{array}{l}\text { F: protein kinase activity; } \\
\text { F: ATP binding; } \\
\text { P: protein phosphorylation }\end{array}$ \\
\hline Q9M3Н3 & Annexin & 1.27 & 0.01 & $\begin{array}{l}\text { F: calcium ion binding; } \\
\text { F: calcium-dependent phospholipid binding }\end{array}$ \\
\hline M0ZXE4 & $\begin{array}{l}\text { Uncharacterized protein contains a } \\
\text { domain found in serine peptidases }\end{array}$ & 1.27 & 0.02 & $\begin{array}{l}\text { F: serine-type endopeptidase activity; } \\
\text { P: proteolysis }\end{array}$ \\
\hline Q4FE26 & Proteinase inhibitor 1 PРI3В2 & 1.26 & 0.03 & $\begin{array}{l}\text { F: serine-type endopeptidase inhibitor } \\
\text { activity; } \\
\text { P: response to wounding }\end{array}$ \\
\hline M1ABL9 & $\begin{array}{l}\text { Uncharacterized protein contains } \\
\text { AAA+ ATPase domain }\end{array}$ & 1.25 & 0.003 & F: ATP binding and hydrolysis \\
\hline Q84XQ4 & NtPRp27-like protein & 1.25 & 0.02 & \\
\hline M1A4R1 & $\begin{array}{l}\text { Uncharacterized protein with AT } \\
\text { hooks a DNA-binding motif }\end{array}$ & 1.24 & 0.004 & $\begin{array}{l}\text { C: nucleosome; } \\
\text { F: DNA binding; } \\
\text { C: nucleus; } \\
\text { P: nucleosome assembly }\end{array}$ \\
\hline M1C8Q0 & $\begin{array}{l}\text { Uncharacterized protein contains } \\
\text { Proteasome component Initiation } \\
\text { (PCI) domain }\end{array}$ & 1.22 & 0.02 & F: enzyme regulator activity \\
\hline
\end{tabular}


Table 1. Cont.

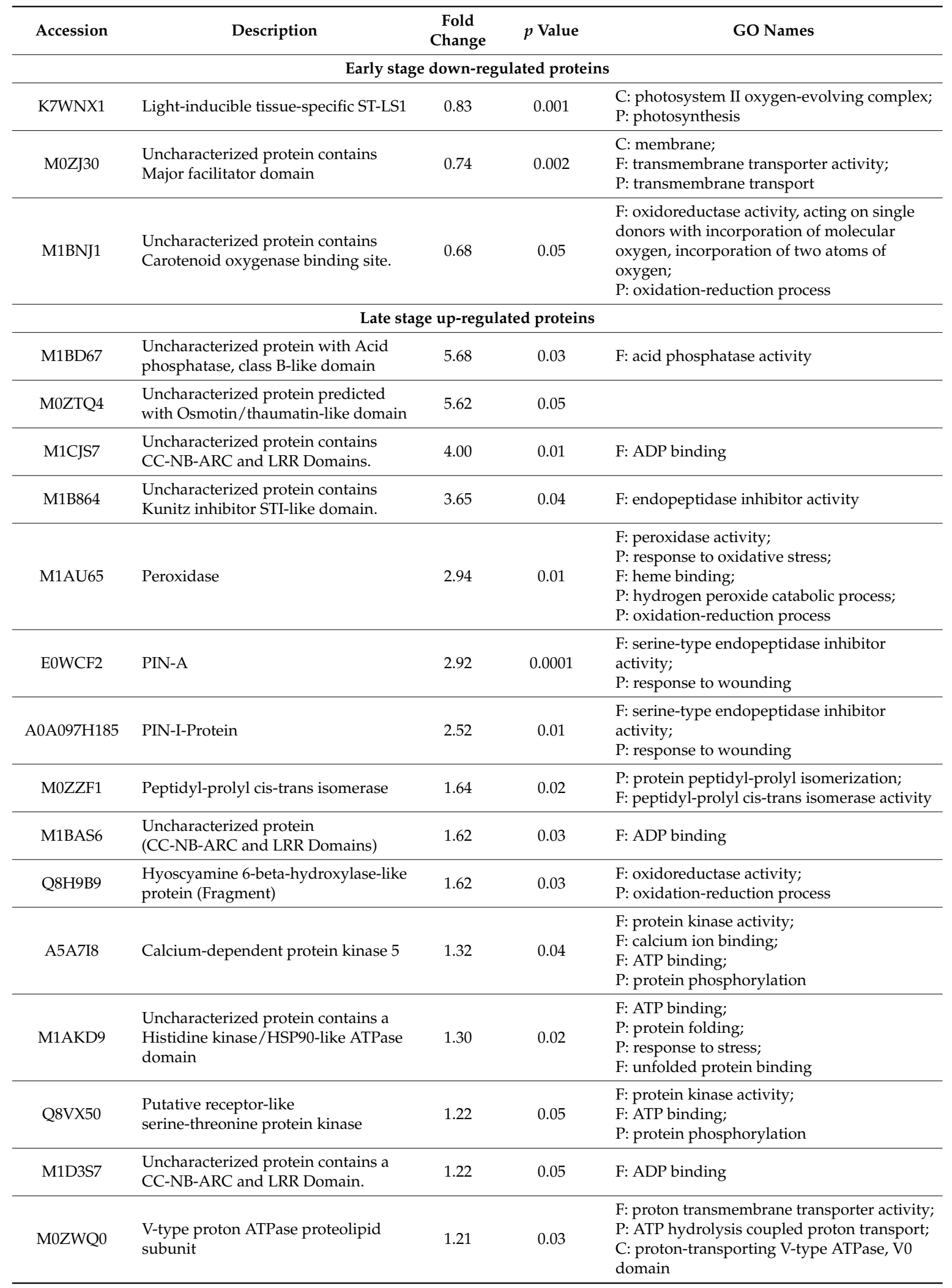


Table 1. Cont.

\begin{tabular}{|c|c|c|c|c|}
\hline Accession & Description & $\begin{array}{c}\text { Fold } \\
\text { Change }\end{array}$ & $p$ Value & GO Names \\
\hline \multicolumn{5}{|c|}{ Late stage down-regulated proteins } \\
\hline K7WNV9 & Thioredoxin & 0.82 & 0.05 & $\begin{array}{l}\text { P: glycerol ether metabolic process; F: protein } \\
\text { disulfide oxidoreductase activity; } \\
\text { P: cell redox homeostasis }\end{array}$ \\
\hline G1CCA4 & Photosystem I assembly protein Ycf4 & 0.71 & 0.03 & $\begin{array}{l}\text { C: photosystem I; } \\
\text { P: photosynthesis; } \\
\text { C: integral component of membrane }\end{array}$ \\
\hline M1D260 & FK506-binding protein & 0.63 & 0.03 & $\begin{array}{l}\text { P: histone peptidyl-prolyl isomerization; } \\
\text { F: peptidyl-prolyl cis-trans isomerase activity; } \\
\text { F:FK506 binding; } \\
\text { C: nucleolus }\end{array}$ \\
\hline M1B8N6 & $\begin{array}{l}\text { NADPH-protochlorophyllide } \\
\text { oxidoreductase }\end{array}$ & 0.37 & 0.04 & $\begin{array}{l}\text { F: protochlorophyllide reductase activity; } \\
\text { P: oxidation-reduction process }\end{array}$ \\
\hline
\end{tabular}

\subsubsection{Cv. Sarpo Mira Protein-Protein Interaction during the Early Stages of Infection}

Most proteins carry out essential biological functions, like signal transduction, protein modification, cellular metabolism, cytokinesis, DNA replication, RNA transcription, and targeted degradation, by interacting with other proteins in a protein complex. To uncover functional interactions among proteins during the early stages of $P$. infestans invasion, we analyzed the 75 DEPs in the EI/Control comparison by Search Tool for the Retrieval of Interacting Genes/Proteins (https://string-db.org) in Cytoscape (Figure 7a). Of interest, was the association among nine proteins: wall-associated kinase protein (WAKP, M1D051), an integral component of the cell membrane; a ubiquitin-conjugating enzyme protein (M1BLH0); a chloroplast nucleoid DNA-binding protein (M1B6K1); a ribosomal L24 domain (M1D1L9); a 26S proteasome subunit-containing RPN7 protein domain (M1C8Q0); endochitinase (Q2HPK8); osmotin (M0ZTM9); a pathogenesis-related PR1 protein containing a RlpA-like double-psi beta-barrel domain (M1A2A4); and finally, protein disulfide isomerase inhibitor (PDI, M1C517).

We reasoned that $P$. infestans might directly or indirectly elicit the induction of these proteins, and their association was important to promote coordination of several processes, including signal transduction, cellular metabolic process, and defense against $P$. infestans. For example, WAKP (M1D051, $F C=1.28)$ was predicted as a major functional node having multiple protein interactions, and it was specifically significantly up-regulated from Control to EI time-points, through to LI. Previous studies have shown that WAK proteins are important oligogalacturonide receptors, required for the activation of the plant immune response, as well as for growth and development [59]. Additionally, there are reports of the arabidopsis RFO1 gene coding for a wall-associated kinase protein that conferred quantitative resistance against Fusarium oxysporum [60]. In the present study, it is likely that WAKP, in association and coordination with other proteins, acted as an elicitor by binding to damage-associated molecular patterns (DAMPs) or cell wall defense proteins [61,62]. We also noticed that a putative ribosomal protein in the network was highly abundant (M1D1L9, FC $=1.36$ ), and a protein possessing ubiquitin-binding domain (M1C8Q0, FC = 1.22). Previous studies have reported the involvement of these two proteins in P. parasitica-tomato interaction [63]. Next are the constitutively highly-expressed Endochitinase proteins (Q2HPK8, FC = 1.43; M1AH25, FC =1.33), which have common function in defense-related signaling to boost the non-specific defense response by releasing elicitor-active chitin oligomers [60]. It has been shown that basic chitinase and osmotin-like protein possess actin-binding capabilities and cooperate to promote cytoplasmic aggregation in the potato cells, as a defense against penetration of Phytophthora [64]. In the present study, the significant up-regulation of these several osmotins, (M0ZTM9, FC = 1.34) from Control to EI, and through to LI, suggest significant coordination among pathogenesis-related proteins within the cell wall to promote basal resistance responses. Indeed, the PR1 gene was implicated in basal resistance against $P$. infestans oomycete [65]. In this study, PR1 
protein $(F C=1.30)$ was up-regulated, its expression level was highest at the late stage $(1.40)$, which indicates that this protein was significantly induced throughout the time course, which is consistent with previous studies [66]. Also, the KiTH-2 protein was strongly up-regulated (FC =1.82) upon infection with $P$. infestans; its specific role in potato-P. infestans interaction or pathogen resistance is not clear [67]. Although it belongs to the Kiwellin family and contains the rare lipoprotein A (RlpA) domain, which has been shown to act as a prc mutant suppressor in Escherichia coli [68]. Here, we speculate that it may function as part of elicitor machinery during pathogen infection.

Meanwhile, studies have shown that the PDI gene (FC $=1.31$, M1C517) plays a crucial role in host-pathogen interaction and that PDI protein is localized to the haustoria of Phytophthora, a major site of pathogen protein export into the host cell during infection [69]. In the present study, the significant up-regulation of PDI from Control to EI, and subsequent decrease in abundance at LI, suggests this protein might be acting as a virulence factor of $P$. infestans at the early infection stage, and potentially contributes to plant infection and the late-stage disease process [70]. Additionally, the plant's secretory system is crucial for building resistance at the cell periphery. It also enables attacked cells to transport antimicrobial compounds and cell wall material to the site of attempted penetration [38]. In this study, we found a vesicle-mediated transport protein (M0ZZ55, FC = 1.77) containing the v-SNARE domain, significantly up-regulated from Control to EI, and with stable expression afterward, which suggests a tightly coordinated transport process during early stages of pathogen attack, which has been previously reported [69]. Together, these results show that during the early stages of disease infection there was a coordinated up-regulation of defense arsenal, like the pathogen recognition proteins, signaling molecules, antimicrobial compounds, cellular trafficking, primed to initiate a broad-based resistance against $P$. infestans.

\subsubsection{Cv. Sarpo Mira Protein-Protein Interaction during the Late Stages of Infection}

We analyzed the protein interaction of DEPs identified in LI/EI comparison and found multifactorial interactions with several hub proteins in the network (Figure $7 \mathrm{~b}$ ). Prominent among the proteins in the network was urease (Q93WI8, FC $=1.27$ ), with over 67 connections. In this study, urease increased slightly in abundance from Control (avg. $=0.86$ ) to EI (avg. $=0.90)$, but was significantly induced at LI (avg. = 1.14). Studies have shown that urease inhibits the growth of phytopathogenic fungi [71,72]. We also found an uncharacterized protein, M1E0E5 (FC = 1.22), with 57 connections, which contained a pyridoxal-phosphate-binding site, and was predicted to participate in aminotransferase activity, oxidoreductase, and mononucleotide binding. Similarly, we observed two other proteins (57 connections) coding for Hydroxyacyl-CoA dehydrogenase (M0ZHQ8, FC $=1.26$ ), with functions related to oxidoreductase activity. Other proteins included metalloenzyme (39 connections, O81394, FC $=-1.20$ ), involved in catalytic conversion of 2-phosphoglycerate to phosphoenolpyruvate; GA3PDH enzyme (34 connections, Q8LK04, FC $=1.20$ ), involved in glycolysis and gluconeogenesis; citrate synthase protein (32 connections, M1AD15, FC $=1.38$ ); histidine kinase/HSP90-like ATPase (32 connections, M1C5D1, FC $=1.21$ ); thioredoxin (28 connections, M1CXH6, FC = 1.24); and glutathione peroxidase (20 connections, M1AWZ7, FC = 1.37).

The late stage of the P. infestans disease process is usually characterized by colonization and necrotrophy [48]. At this stage, it is also likely that the pathogen faced a shortage of nutrients, like glucose, fatty acid, amino acids, and energy, from the shut-down of the host's cellular metabolism by HR-induced cell death, and may attempt to induce host metabolic changes to enable nutrient supply and growth. For example, GA3PDH was up-regulated and is required for the breakdown of glucose for energy and carbon molecules. Hydroxyacyl-CoA dehydrogenase is essential for fatty acid beta-oxidation, which can also provide energy. While pyridoxal phosphate P5P is an active form of vitamin B6, which is known to be involved in various reactions, including amino acid break-down, transamination, decarboxylation, and racemization reactions. It is likely that P5P acts to counteract the toxic effects of the oxidative burst and, alternatively, to break down amino acids for energy, possibly contributing to pathogenesis. Additionally, for the pathogen colonization to succeed, it must 
inactivate or remove the host-induced reactive oxygen species (ROIs), and thioredoxin proteins can counteract or protection the pathogen against ROIs [48]. Other proteins that showed sparse interaction included: cytochrome P450 proteins, possibly involved in efflux and detoxification [62]; and anamorsin; interestingly, anamorsin has been reported to be involved in negative regulation of apoptosis as well as cellular iron homeostasis [73]. Likewise, we noticed glycosyl hydrolase, a cell wall-degrading enzyme, was probably involved in virulence as well as nutrition or growth at the late disease stage.

We also identified glutathione S-transferase and glutathione peroxidase, which were previously reported to be involved in pathogen antioxidant defenses and host cell detoxication [62,74]. Based on these results we hypothesize that in an incompatible interaction some of the DEPs at the late stage may have a function-related late-stage disease-susceptible process. Notwithstanding, a strong domain self-interaction was observed among the cell death regulator proteins (M1D3S7, M1CJS7, M1BAS6) at this stage.

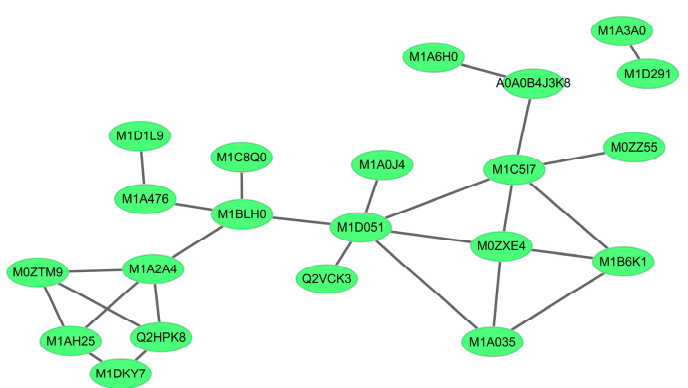

(a)

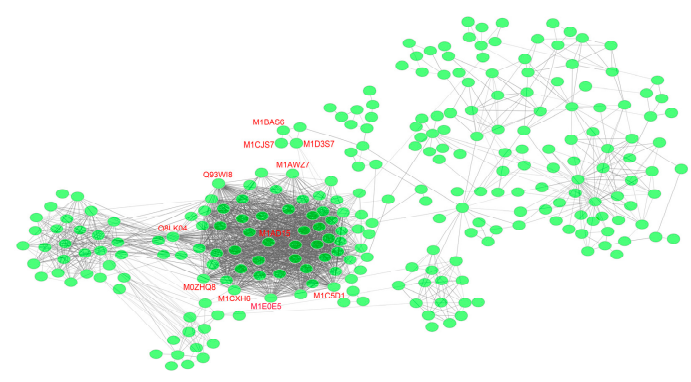

(b)

Figure 7. Network analysis results for significantly changed proteins in the (a) early and (b) late stages of infection.

\subsubsection{Correlation Analysis of Protein Expression and mRNA by Real Time-qPCR}

In order to evaluate the correlation between mRNA and protein levels, we analyzed the relative expression pattern of genes encoding eight representative proteins in the context of the three time-points by RT-qPCR. For each of the eight genes, we found that the transcript level increased in the early and late stage of the disease process, in agreement with their protein expression levels, as revealed by TMT data. For example, in the early stages of disease infection, three of the eight genes, coding for proteins involved in cell wall structure modification, had a higher expression level (Figure 8a). A similar pattern was observed for the remaining five genes at the later stage of the infection cycle (Figure $8 b$ ). These results validate the increased levels of the encoded proteins that were observed in the proteomic analysis and suggest that the abundance of these proteins is likely regulated at the transcriptional level. 


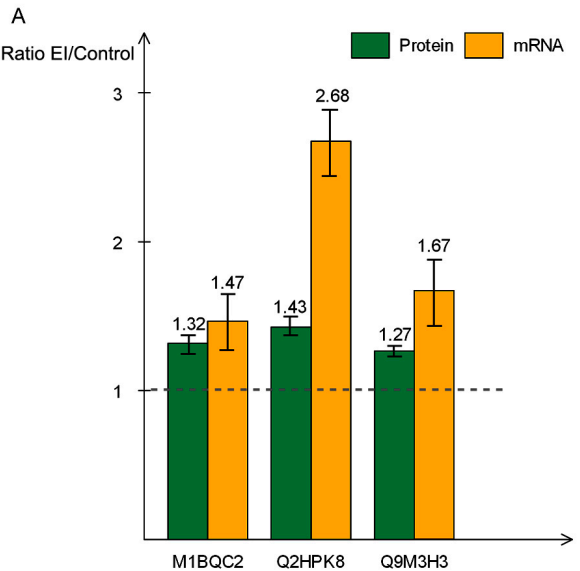

(a)

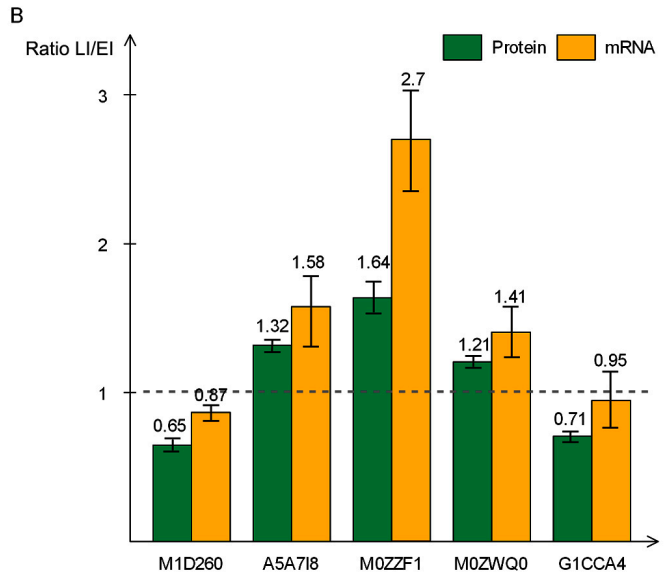

(b)

Figure 8. Real-time polymerase chain reaction (PCR) quantitative analysis of eight differentially-expressed proteins and mRNA at early (a) and late (b) disease stages. The green bar indicates the expression level determined by Tandem mass tag (TMT) and orange bar shows relate expression of mRNA. All data are presented as mean $\pm \mathrm{SD}$ ( $n=3$ in each time-point).

In summary, this study sheds light on the changes in protein abundance and physiological roles of proteins in potato during the early and late stages of $P$. infestans oomycete infection. We have also inferred protein interaction that occurred during the two disease stages, either physical interactions verified through experiments, or predictions to further understand the disease process. Overall, our analysis suggests that differentially-expressed proteins, identified at the early stage of infection, played significant roles in signal transduction and the basal defense response, while the late stage disease process was characterized by the significant abundance of $R$ proteins related to disease resistance processes and cell death. However, some of proteins in the late disease stage could be related to late-stage disease-susceptible processes. Therefore, the data reported here is a valuable resource for practical use to further characterize the mechanisms that are potentially involved in the potato late blight disease resistance process.

\section{Materials and Methods}

\subsection{Plant Material and Growth Conditions}

Potato plants of cultivar Sarpo Mira were grown in a greenhouse with controlled conditions set at $20{ }^{\circ} \mathrm{C}, 16: 8$ light to dark cycle, and $70 \%$ relative humidity. Five-week-old plants were transferred to an infection chamber with 100\% humidity and 10:14 light:dark cycle. After $6 \mathrm{~h}$, plants were sprayed with an encysted zoospore suspension from $P$. infestans isolate until the leaf surfaces were fully saturated with the zoospore suspension $(15,000$ sporangia/mL). Samples were collected at 0,48 , and $120 \mathrm{~h}$ post inoculation (hpi) according to [75], and labelled as Control, EI, and LI, respectively. The 0 dpi samples were collected immediately after inoculation with a contact time of less than one minute [75]. Afterwards, the relative humidity was maintained at $100 \%$ for two days after inoculation and then adjusted to $90 \%$ for the rest of the experiment. For each time-point, samples of fully-expanded upper leaves were collected from three independent biological experiments. All the materials were frozen in liquid nitrogen and stored at $-80{ }^{\circ} \mathrm{C}$ until use [31].

\subsection{Protein Extraction}

For each sample, $1 \mathrm{~g}$ was weighed and homogenized by grinding in liquid nitrogen and transferred to a $50 \mathrm{~mL}$ precooled test-tube. Afterwards $25 \mathrm{~mL}$ of precooled acetone $\left(-20^{\circ} \mathrm{C}\right)$, containing $10 \%(\mathrm{v} / \mathrm{v})$ trichloroacetic acid (TCA) and $65 \mathrm{mM}$ dithiothreitol (DTT), was added. After thorough mixing, the homogenate was precipitated for $2 \mathrm{~h}$ at $-20^{\circ} \mathrm{C}$ and then centrifuged for $30 \mathrm{~min}$ at $16,000 \times g$ at $4{ }^{\circ} \mathrm{C}$. 
The supernatant was carefully removed, and the pellet was rinsed three times with $20 \mathrm{~mL}$ of cold acetone $\left(-20^{\circ} \mathrm{C}\right)$, followed by centrifugation $\left(20,000 \times \mathrm{g}\right.$ for $30 \mathrm{~min}$ at $\left.4{ }^{\circ} \mathrm{C}\right)$. The precipitation was collected and vacuum freeze-dried. A $250 \mathrm{mg}$ sample of the freeze-dried pellets was weighed and placed in a $1.5 \mathrm{~mL}$ Eppendorf tube. The pellets were dissolved in SDT lysis buffer (4\% SDS, $100 \mathrm{mM}$ Tris-HCl, $100 \mathrm{mM} \mathrm{DTT}, \mathrm{pH} \mathrm{8.0)}$ and then boiled for $5 \mathrm{~min}$. After boiling and vortex mixing for $30 \mathrm{~s}$, the mixture was intermittently sonicated in an ice bath, with $5 \mathrm{~s}$ sonication followed by $10 \mathrm{~s}$ break, for $5 \mathrm{~min}$ at $100 \mathrm{~W}$. The mixture was then boiled again for $5 \mathrm{~min}$, followed by $30 \mathrm{~min}$ centrifugation $(12,000 \times g$, $20^{\circ} \mathrm{C}$ ). The supernatant was collected in a new $1.5 \mathrm{~mL}$ Eppendorf tube, filtered through a $0.22-\mu \mathrm{m}$ Millipore filter and collected as lysate. Protein concentration in the lysate was determined using the bicinchoninic acid (BCA) protein assay reagent (Beyotime Institute of Biotechnology, Shanghai, China). The rest of the lysate was frozen at $-80^{\circ} \mathrm{C}$ until use.

\subsection{Protein Digestion}

TMT analysis was performed according to the method described by [76], Briefly, protein concentrates $(300 \mu \mathrm{g})$ in an ultrafiltration filtrate tube (30 kDa cut-off, Sartorius, Gottingen, Germany) was mixed with $200 \mu \mathrm{L}$ Urea buffer $(8 \mathrm{M}$ urea, $150 \mathrm{mM}$ Tris- $\mathrm{HCl}, \mathrm{pH} 8.0)$ and the sample was centrifuged at $14,000 \times g$ at $20^{\circ} \mathrm{C}$ for $30 \mathrm{~min}$. The sample was washed twice by adding $200 \mu \mathrm{L} \mathrm{UA}$ and centrifuged at $14,000 \times g$ at $20^{\circ} \mathrm{C}$ for $30 \mathrm{~min}$. The flow-through from the collection tube was discarded. Next, $100 \mu$ L Indole-3-acetic acid (IAA) solution (50 mM IAA in UA buffer) was added to the filter tube and vortexed at $600 \mathrm{rpm}$ in a thermomixer comfort incubator (Eppendorf, Germany) for $1 \mathrm{~min}$. Subsequently, the sample was incubated at room temperature for $30 \mathrm{~min}$ in the dark and spun at $14,000 \mathrm{~g}$ for $30 \mathrm{~min}$ at $20^{\circ} \mathrm{C}$. Next $100 \mu \mathrm{L}$ UA was added to the filter unit and centrifuged at $14,000 \mathrm{~g}$ for $20 \mathrm{~min}$, and this step was repeated twice. The protein suspension in the filtrate tube was subjected to enzyme digestion with $40 \mu \mathrm{L}$ of trypsin (Promega, Madison, WI, USA) buffer (4 $\mu$ g trypsin in $40 \mu \mathrm{L}$ of dissolution buffer) for $16-18 \mathrm{~h}$ at $37^{\circ} \mathrm{C}$. Finally, the filter unit was transferred to a new tube and spun at 14,000 $\mathrm{g}$ for $30 \mathrm{~min}$. Peptides were collected in the filtrate and concentration of the peptides was measured by optical density with a wavelength of $280 \mathrm{~nm}$ (OD280).

\subsection{TMT Labeling and LC-MS/MS Analysis}

Approximately 50ug of digested peptides from each sample, including the internal standard, were labeled with TMT reagents (Thermo Fisher Scientific, San Jose, CA, USA) following procedures recommended by the manufacturer. Briefly, peptides from the samples LI1, LI2, LI3, Control 1, Control 2, Control 3, EI 1, EI 2, and EI3 were labeled with TMT reagents 126, 127N, $127 \mathrm{C}, 128 \mathrm{~N}, 128 \mathrm{C}, 129 \mathrm{~N}$, $130 \mathrm{~N}, 130 \mathrm{C}$, and 131, respectively. All labeled peptides were pooled together. Labeled and mixed peptides were subjected to high-pH reversed-phase fractionation in the 1100 Series High-performance liquid chromatography Value System (Agilent, Palo Alto, CA, USA) equipped with a Gemini-NX (Phenomemex, 00F-4453-E0) column $(4.6 \times 150 \mathrm{~mm}, 3 \mu \mathrm{m}, 110 \AA$ Å). Peptides were eluted at a flow rate of $0.8 \mathrm{~mL} / \mathrm{min}$. Buffer A consisted of $10 \mathrm{mM}$ ammonium acetate (pH10.0) and buffer B consisted of $10 \mathrm{mM}$ ammonium acetate and $90 \% v / v$ Acetonitrile ( $\mathrm{pH}$ 10.0). Buffer A and B were both filter-sterilized. The following gradient was applied to perform separation: $100 \%$ buffer A for $40 \mathrm{~min}, 0 \%-5 \%$ buffer B for $3 \mathrm{~min}, 5 \%-35 \%$ buffer B for $30 \mathrm{~min}$, and 35\%-70\% buffer B for $10 \mathrm{~min}$. Then, $70 \%-75 \%$ buffer B for $10 \mathrm{~min}, 75 \%-100 \%$ buffer B for $7 \mathrm{~min}, 100 \%$ buffer B for $15 \mathrm{~min}$, and 100\% buffer A for $15 \mathrm{~min}$. The elution process was monitored by measuring absorbance at $214 \mathrm{~nm}$, and fractions were collected every $75 \mathrm{~s}$. Finally, the collected fractions (approximately 40) were combined into 10 pools. Each fraction was concentrated via vacuum centrifugation and was reconstituted in $40 \mu \mathrm{L}$ of $0.1 \% v / v$ trifluoroacetic acid. All samples were stored at $-80^{\circ} \mathrm{C}$ until further analysis.

The TMT-labeled samples were analyzed using easy-nLC nanoflow HPLC system connected to an Orbitrap Elite mass spectrometer (Thermo Fisher Scientific, San Jose, CA, USA). A total of $1 \mu \mathrm{g}$ of each peptide sample was loaded onto Thermo Scientific EASY column (two columns) using an autosampler at a flow rate of $150 \mathrm{~nL} / \mathrm{min}$. The sequential separation of peptides on Thermo Scientific 
EASY trap column $(100 \mu \mathrm{m} \times 2 \mathrm{~cm}, 5 \mu \mathrm{m}, 100 \AA, C 18)$ and analytical column $(75 \mu \mathrm{m} \times 25 \mathrm{~cm}, 5 \mu \mathrm{m}$, $100 \AA$, C18) was accomplished using a segmented $2 \mathrm{~h}$ gradient from Solvent A $(0.1 \%$ formic acid in water) to $35 \%$ Solvent B ( $0.1 \%$ formic acid in $100 \%$ Acetonitrile) for $100 \mathrm{~min}$. Followed by $35 \%-90 \%$ Solvent B for $12 \mathrm{~min}$ and then $90 \%$ Solvent B for $8 \mathrm{~min}$. The mass spectrometer was operated in positive ion mode, and MS spectra were acquired over a range of 350-2000 m/z. Resolving powers of the MS scan and MS/MS at $100 \mathrm{~m} / \mathrm{z}$ for the Orbitrap Elite were set as 60,000 and 15,000, respectively. The top sixteen most intense signals in the acquired MS spectra were selected for further MS/MS analysis. The isolation window was $1 \mathrm{~m} / z$, and ions were fragments through higher energy collisional dissociation with normalized collision energies of $35 \mathrm{eV}$. The maximum ion injection time was set at $50 \mathrm{~ms}$ for the survey scan, and $150 \mathrm{~ms}$ for the MS/MS scans, and the automatic gain control target values for full san modes was set to $10 \times 10^{-6}$, and for MS/MS it was $5 \times 10^{4}$. The dynamic exclusion duration was $30 \mathrm{~s}$.

\subsection{Database Search, Protein Identification, and Quantification}

The Proteome Discoverer 2.1 (Thermo Fisher Scientific) was used to analyze raw data. The Mascot 2.1 (Matrix Science) embedded in Proteome Discoverer was used to search raw data against the UniProt potato database (December 21, 2017; 55,715 sequences). Search parameters were as follows: monoisotopic mass; trypsin as cleavage enzyme; two max missed cleavages; TMT 10plex (N-term), TMT 10plex (K), and carbamidomethylation of cysteine as fixed modifications; and oxidation of methionine as variable modifications. Peptide mass tolerance of $\pm 20 \mathrm{ppm}$ and fragment mass tolerance of 0.1 Da were used for parent and monoisotopic fragment ions, respectively. Results were filtered based on a false discovery rate of (FDR) $\leq 0.01$. Relative quantitative analyses of proteins were based on ratios of TMT reporter ions from all unique peptides representing each protein. For protein quantitation, each reporter ion channel was summed across all quantified proteins and normalized assuming equal protein loading of all ten samples. The protein ratios of each sample were normalized to the TMT-126 label [77]. The mass spectrometry proteomics data are available at ProteomeXchange Consortium via the PRIDE [78] partner repository with identifier PXD010045.

\subsection{Bioinformatics and Statistical Analysis}

Proteome Discoverer 2.1 Protein quantitation values were exported for further analysis in Excel. Proteins of $p$-values $<0.05$ by Student $t$-test and a fold-change of $>1.20$ or $<0.83$ in expression between any two groups were considered significant. Differentially expressed proteins (DEPs) were classified by their gene functions and also by biological pathways using the publicly available gene ontology (GO) database provided by the Gene Ontology Consortium (http://geneontology.org/) [79]. The identified protein sequence information was extracted from the UniProt knowledge base and retrieved in FASTA format. The functional information of the homologous proteins was used to annotate targeted proteins. Top 10 blast hits with E-values of less than 1e-3, for each of the query proteins, were retrieved and loaded into Blast2GO (Version 2.7.2) [80], a high-throughput online tool for gene ontology (GO) analysis, for GO mapping, and annotation. Enriched GO terms were identified with Fisher's exact test and hypergeometric distribution test cutoff of 0.05 . Information on the biological pathways was obtained from the Kyoto Encyclopedia of Genes and Genomes pathways database (http://www. genome.jp/kegg/pathway.html) [81]. Visualization of these pathways and enrichment analysis was performed using the KOBAS 2.0 software [82-84]. $p<0.05$ was set as the threshold used for enrichment analysis of KEGG pathways. Interactions among differentially-expressed proteins in early and late disease stages were analyzed by Cytoscape software, and were used to draw the protein interaction network [82].

\subsection{Antibodies and Western Blot Analysis}

For western blot analysis, the procedures of electrophoresis, transfer, and immunodetection were performed according to Howden et al. [85]. The primary antibodies used were as follows: 
antibody for the Osmotin-like protein (Q5XUH0, Biorbyt orb27915, 1:1000); pectinesterase (M1BQC2, PLLABS PL0304687, 1:500); endochitinase (Q2HPK8, PhytoAB PHY1514S, 1:2000); annexin (Q9M3H3, PhytoAB PHY0729S, 1:2000); peptidyl-prolyl cis-trans isomerase (M0ZZF1, PhytoAB PHY0920S, 1:2000); photosystem I assembly protein Ycf4 (G1CCA4, PhytoAB PHY1363S, 1:1500); type I serine protease inhibitor (E0WCF2, PhytoAB PHY0146S, 1:2000). Horseradish peroxidase-conjugated anti-rabbit IgG (dilution 1:15,000, Bio-Rad, Hercules, CA, USA) were used as secondary antibodies. After immunodetection, the intensity of the immuno-stained bands were normalized for the total protein intensities measured by Coomassie blue from the same [86]. The images were subjected to densitometric analysis performed using Quantity One software (Bio-Rad).

\subsection{Criteria for Selecting Essential Proteins}

Candidate proteins were selected belonging to the following groups: (a) Common and unique DEPs belonging to the early disease stage, chosen based on their protein abundance, fold change value, and functional category enrichment. Additionally, candidates were further selected based on the inferred protein interaction as well as those with putative function that are relevant to late blight disease infection response during early infection. Furthermore, previously reported proteins were also considered in candidate gene selection in both stages. (b) Common and unique DEPs from the late disease stage, chosen based on expression profile, fold change value, functional category enrichment, and putative function relevant to the late disease stage disease process, in addition to the inferred protein interactions in the network.

\subsection{Correlation between $m R N A$ and Protein Levels by Quantitative Real-Time Polymerase Chain Reaction $(q R T-P C R)$}

Leaf samples were collected at 4, 48, and $120 \mathrm{~h}$ for protein and total RNA isolation. Total RNA was extracted from each sample using TRIzol Reagent Kit (AmbionTM) according to the manufacturer's instructions. Next, each of the RNA samples was treated with RNase-free DNase (Takara, Dalian, China). Complementary DNA (cDNA) was retro-transcribed from $2 \mu \mathrm{g}$ of total RNA using the Thermo Scientific RevertAid Kit according to the manufacturer's instructions. Quantitative real-time polymerase chain reaction (qPCR) was performed on a Bio-Rad real-time detection system (Bio-Rad). PCR conditions were $95^{\circ} \mathrm{C}$ for $1 \mathrm{~min}$, followed by 44 cycles at $95{ }^{\circ} \mathrm{C}, 12 \mathrm{~s}, 60^{\circ} \mathrm{C}, 30 \mathrm{~s}$, and $72{ }^{\circ} \mathrm{C}$, $30 \mathrm{~s}$. After cycling, melting curves of the reaction were run from $55^{\circ} \mathrm{C}$ to $95^{\circ} \mathrm{C}$. Each reaction was performed in three technical replicates, and the expression profiles of 8 genes were analyzed, with potato efla gene used as the constitutive gene for normalization. The quantification of gene expression levels was calculated relative to efla with the $2^{-\Delta \Delta C T}$ method [87]. Primer sets used for qRT-PCR are reported in Table S8.

Supplementary Materials: Supplementary materials can be found at http:/ / www.mdpi.com/1422-0067/20/ 1/136/s1. Table S1: List of all proteins identified in the time series analysis. Table S2: List of all differentially expressed proteins, functional annotation, significantly enriched INTERPRO protein domains and features, PFAM domains, and KEGG pathways classification. Table S3: List of differentially-expressed proteins during the early stage of $P$. infestans infection. (EI/Control). Table S4: List of differentially-expressed proteins during the late stage of $P$. infestans infection. (LI/EI). Table S5: List of differentially-expressed proteins from time-point LI/Control. Table S6: Gene Ontology classification of differentially-expressed proteins. Table S7: List of common differentially-expressed proteins throughout the whole time course of the experiment. Table S8: List of primer sets used in the qRT-PCR correlation analysis of protein expression and mRNA.

Author Contributions: Conceptualization, S.Y.; methodology, Q.C. (Qiaoling Chen), L.Y., J.G., and C.X.; validation, J.G., Y.Z., G.Y., C.X., and L.Y.; formal analysis, Z.W., D.Z., Y.X., Y.Z., and Q.C. (Qun Cheng); investigation, C.X., J.G., X.Y., G.Y., and Y.X.; resources, S.Y., C.X., and J.C.; data curation, L.Y., C.X., Z.W., and D.Z.; writing-original draft preparation, C.X. and J.C.; writing-review and editing, S.Y., J.C., C.X., Y.X., X.Y., and Q.C. (Qiaoling Chen); visualization, X.Y., G.Y., Q.C. (Qun Cheng), and Y.X.; supervision, S.Y. and J.C.; project administration, S.Y.; funding acquisition, S.Y., C.X., and J.C.

Funding: This research was funded by Hubei Provincial Specialized Technological Innovation Project (Special Project of Western Hubei Ethnic Group2016AKB052); China Agriculture Research System (CARS-09); Central Guidance for Local Science and Technology Development; Ministry of Agriculture Central China Potato 
Observation and Experiment Station; Ministry of Agriculture Key Laboratory of Agro-Products Postharvest Handing (KLAPPH2-2017-05); Innovation Team of Hubei Agricultural Science and Technology Innovation Center (2016-620-000-001-061); and Enshi Prefecture Science and Technology Plan Research and Development Project (D20170003).

Acknowledgments: The authors gratefully acknowledge Shanghai Omicsspace Biotechnology Co., Ltd. and Charles. C. Nwafor for technical assistance with peptide and protein identification and the discussion of the results.

Conflicts of Interest: The authors have declared that no competing interest exist.

\section{References}

1. Song, J.; Bradeen, J.M.; Naess, S.K.; Raasch, J.A.; Wielgus, S.M.; Haberlach, G.T.; Lui, J.; Kuang, H.; Austin-Phillips, S.; Buell, C.R.; et al. Gene RB cloned from Solanum bulbocastanum confers broad spectrum resistance to potato late blight. Proc. Natl. Acad. Sci. USA 2003, 100, 9128-9133. [CrossRef] [PubMed]

2. Haas, B.J.; Kamoun, S.; Zody, M.C.; Jiang, R.H.Y.; Handsaker, R.E.; Cano, L.M.; et al. Genome sequence and analysis of the Irish potato famine pathogen Phytophthora infestans. Nature 2009, 461, 393-398. [CrossRef] [PubMed]

3. Widmark, A.K.; Andersson, B.; Cassel-Lundhagen, A.; Sandström, M.; Yuen, J.E. Phytophthora infestans in a single field in southwest Sweden early in spring: Symptoms, spatial distribution, and genotypic variation. Plant Pathol. 2007, 56, 573-579. [CrossRef]

4. Zuluaga, A.P.; Vega-Arreguín, J.C.; Fei, Z.; Ponnala, L.; Lee, S.J.; Matas, A.J.; Patev, S.; Fry, W.E.; Rose, J.K. Transcriptional dynamics of Phytophthora infestans during sequential stages of hemibiotrophic infection of tomato. Mol. Plant Pathol. 2016, 17, 29-41. [CrossRef]

5. Kaku, H.; Nishizawa, Y.; Ishii-Minami, N.; Akimoto-Tomiyama, C.; Dohmae, N.; Takio, K.; Minami, E.; Shibuya, N. Plant cells recognize chitin fragments for defense signaling through a plasma membrane receptor. Proc. Natl. Acad. Sci. USA 2006, 103, 11086-11091. [CrossRef]

6. Hayafune, M.; Berisio, R.; Marchetti, R.; Silipo, A.; Kayama, M.; Desaki, Y.; Arima, S.; Squeglia, F.; Ruggiero, A.; Tokuyasu, K.; et al. Chitin-induced activation of immune signaling by the rice receptor CEBiP relies on a unique sandwich-type dimerization. Proc. Natl. Acad. Sci. USA 2014, 111, E404-E413. [CrossRef]

7. Shimizu, T.; Nakano, T.; Takamizawa, D.; Desaki, Y.; Ishii-Minami, N.; Nishizawa, Y.; Minami, E.; Okada, K.; Yamane, H.; Kaku, H.; et al. Two LysM receptor molecules, CEBiP and OsCERK1, cooperatively regulate chitin elicitor signaling in rice. Plant J. 2010, 64, 204-214. [CrossRef]

8. Miya, A.; Albert, P.; Shinya, T.; Desaki, Y.; Ichimura, K.; Shirasu, K.; Narusaka, Y.; Kawakami, N.; Kaku, H.; Shibuya, N. CERK1, a LysM receptor kinase, is essential for chitin elicitor signaling in Arabidopsis. Proc. Natl. Acad. Sci. USA 2007, 104, 19613-19618. [CrossRef]

9. Liu, T.; Liu, Z.; Song, C.; Hu, Y.; Han, Z.; She, J.; Fan, F.; Wang, J.; Jin, C.; Chang, J.; et al. Chitin-induced dimerization activates a plant immune receptor. Science 2012, 336, 1160-1164. [CrossRef]

10. Wan, J.; Zhang, X.C.; Neece, D.; Ramonell, K.M.; Clough, S.; Kim, S.Y.; Stacey, M.G.; Stacey, G. A LysM receptor-like kinase plays a critical role in chitin signaling and fungal resistance in Arabidopsis. Plant Cell 2008, 20, 471-481. [CrossRef]

11. Petutschnig, E.K.; Jones, A.M.E.; Serazetdinova, L.; Lipka, U.; Lipka, V. The lysin motif receptor-like kinase (LysM-RLK) CERK1 is a major chitin-binding protein in Arabidopsis thaliana and subject to chitin-induced phosphorylation. J. Biol. Chem. 2010, 285, 28902-28911. [CrossRef] [PubMed]

12. Narusaka, Y.; Shinya, T.; Narusaka, M.; Motoyama, N.; Shimada, H.; Murakami, K.; Shibuya, N. Presence of LYM2 dependent but CERK1 independent disease resistance in Arabidopsis. Plant Signal. Behav. 2013, 8, e25345. [CrossRef] [PubMed]

13. Shinya, T.; Motoyama, N.; Ikeda, A.; Wada, M.; Kamiya, K.; Hayafune, M.; Kaku, H.; Shibuya, N. Functional characterization of CEBiP and CERK1 homologs in Arabidopsis and rice reveals the presence of different chitin receptor systems in plants. Plant Cell Physiol. 2012, 53, 1696-1706. [CrossRef] [PubMed]

14. Faulkner, C.; Petutschnig, E.; Benitez-Alfonso, Y.; Beck, M.; Robatzek, S.; Lipka, V.; Maule, A.J. LYM2-dependent chitin perception limits molecular flux via plasmodesmata. Proc. Natl. Acad. Sci. USA 2013, 110, 9166-9170. [CrossRef] [PubMed] 
15. Zhang, L.; Kars, I.; Essenstam, B.; Liebrand, T.W.H.; Wagemakers, L.; Elberse, J.; Tagkalaki, P.; Tjoitang, D.; van den Ackerveken, G.; van Kan, J.A. Fungal endopolygalacturonases are recognized as microbe-associated molecular patterns by the Arabidopsis receptor-like protein responsiveness to botrytis polygalacturonases1. Plant Physiol. 2014, 164, 352-364. [CrossRef] [PubMed]

16. Ron, M.; Avni, A. The receptor for the fungal elicitor ethylene-inducing xylanase is a member of a resistance-like gene family in tomato. Plant Cell Am. Soc. Plant Biol. 2004, 16, 1604-1615. [CrossRef] [PubMed]

17. De Jonge, R.; Van Esse, H.P.; Maruthachalam, K.; Bolton, M.D.; Santhanam, P.; Saber, M.K.; Zhang, Z.; Usami, T.; Lievens, B.; Subbarao, K.V.; et al. Tomato immune receptor Ve1 recognizes effector of multiple fungal pathogens uncovered by genome and RNA sequencing. Proc. Natl. Acad. Sci. USA 2012, 109, 5110-5115. [CrossRef]

18. Fradin, E.F.; Zhang, Z.; Ayala, J.C.J.; Castroverde, C.D.M.; Nazar, R.N.; Robb, J.; Liu, C.M.; Thomma, B.P. Genetic dissection of Verticillium wilt resistance mediated by tomato Ve1. Plant Physiol. Am. Soc. Plant Biol. 2009, 150, 320-332. [CrossRef]

19. Jones, J.D.G.; Dangl, J.L. The plant immune system. Nature 2006, 444, 323-329. [CrossRef]

20. Kamoun, S. A catalog of the effector secretome of plant pathogenic oomycetes. Annu. Rev. Phytopathol. 2006, 44, 41-60. [CrossRef]

21. Tian, M.; Benedetti, B.; Kamoun, S. A Second Kazal-like protease inhibitor from Phytophthora infestans inhibits and interacts with the apoplastic pathogenesis-related protease P69B of tomato. Plant Physiol. 2005, 138, 1785-1793. [CrossRef] [PubMed]

22. Metzker, M.L. Sequencing technologies-The next generation. Nat. Rev. Genet. 2010, 11, 31-46. [CrossRef] [PubMed]

23. Goodwin, S.; McPherson, J.D.; McCombie, W.R. Coming of age: Ten years of next-generation sequencing technologies. Nat. Rev. Genet. 2016, 17, 333-351. [CrossRef] [PubMed]

24. Potato Genome Sequencing Consortium. Genome sequence and analysis of the tuber crop potato. Nature 2011, 475, 189-195. [CrossRef] [PubMed]

25. Laurindo, B.S.; Laurindo, R.D.F.; Fontes, P.P.; Vital, C.E.; Delazari, F.T.; Baracat-Pereira, M.C.; da Silva, D.J.H. Comparative analysis of constitutive proteome between resistant and susceptible tomato genotypes regarding to late blight. Funct. Integr. Genom. 2018, 18, 11-21. [CrossRef] [PubMed]

26. Larsen, M.K.G.; Jorgensen, M.M.; Bennike, T.B.; Stensballe, A. Time-course investigation of Phytophthora infestans infection of potato leaf from three cultivars by quantitative proteomics. Data Br. 2016, 6, 238-248. [CrossRef] [PubMed]

27. Ali, A.; Alexandersson, E.; Sandin, M.; Resjö, S.; Lenman, M.; Hedley, P.; Levander, F.; Andreasson, E. Quantitative proteomics and transcriptomics of potato in response to Phytophthora infestans in compatible and incompatible interactions. Bmc Genom. 2014, 15, 497. [CrossRef] [PubMed]

28. Abdallah, C.; Dumas-Gaudot, E.; Renaut, J.; Sergeant, K. Gel-Based and Gel-Free Quantitative Proteomics Approaches at a Glance. Int. J. Plant Genom. 2012, 2012, 494572. [CrossRef] [PubMed]

29. Lim, S.; Borza, T.; Peters, R.D.; Coffin, R.H.; Al-mughrabi, K.I.; Pinto, D.M.; Wang-Pruski, G. Proteomics analysis suggests broad functional changes in potato leaves triggered by phosphites and a complex indirect mode of action against Phytophthora infestans. J. Proteom. 2013, 93, 207-223. [CrossRef]

30. Werner, T.; Sweetman, G.; Savitski, M.F.; Mathieson, T.; Bantscheff, M.; Savitski, M.M. Ion coalescence of neutron encoded TMT 10-plex reporter ions. Anal. Chem. 2014, 86, 3594-3601. [CrossRef]

31. Rietman, H.; Bijsterbosch, G.; Cano, L.M.; Lee, H.R.; Vossen, J.H.; Jacobsen, E.; Visser, R.G.; Kamoun, S.; Vleeshouwers, V.G. Qualitative and quantitative late blight resistance in the potato cultivar Sarpo Mira is determined by the perception of five distinct RXLR effectors. Mol. Plant-Microbe Interact. 2012, 25, 910-919. [CrossRef]

32. Guo, T.; Wang, X.W.; Shan, K.; Sun, W.; Guo, L.Y. The Loricrin-Like Protein (LLP) of Phytophthora infestans is Required for Oospore Formation and Plant Infection. Front. Plant Sci. 2017, 8, 142. [CrossRef] [PubMed]

33. Du, Y.; Mpina, M.H.; Birch, P.R.; Bouwmeester, K.; Govers, F. Phytophthora infestans RXLR Effector AVR1 Interacts with Exocyst Component Sec5 to Manipulate Plant Immunity. Plant Physiol. 2015, 169, 1975-1990. [CrossRef]

34. Quevillon, E.; Silventoinen, V.; Pillai, S.; Harte, N.; Mulder, N.; Apweiler, R.; Lopez, R. InterProScan: Protein domains identifier. Nucleic Acids Res. 2005, 33, W116-W120. [CrossRef] [PubMed] 
35. Yogendra, K.N.; Kumar, A.; Sarkar, K.; Li, Y.; Pushpa, D.; Mosa, K.A.; Duggavathi, R.; Kushalappa, A.C. Transcription factor StWRKY1 regulates phenylpropanoid metabolites conferring late blight resistance in potato. J. Exp. Bot. 2015, 66, 7377-7389. [CrossRef] [PubMed]

36. Fraser, C.M.; Chapple, C. The phenylpropanoid pathway in Arabidopsis. Arab. Book 2011, 9, E0152. [CrossRef]

37. Ah-Fong, A.; Shrivastava, J.; Judelson, H.S. Lifestyle, gene gain and loss, and transcriptional remodeling cause divergence in the transcriptomes of Phytophthora infestans and Pythium ultimum during potato tuber colonization. Bmc Genom. 2017, 18, 764. [CrossRef]

38. Hückelhoven, R. Cell Wall-Associated Mechanisms of Disease Resistance and Susceptibility. Annu. Rev. Phytopathol. 2007, 45, 101-127. [CrossRef]

39. Sanchez, L.M.; Ohno, Y.; Miura, Y.; Kawakita, K.; Doke, N. Host selective suppression by water-soluble glucans from Phytophthora spp. of hypersensitive cell death of suspension-cultured cells from some solanaceous plants caused by hyphal wall elicitors of the fungi. Ann. Phytopathol. Soc. Jpn. 1992, 58, 664-670. [CrossRef]

40. Andreu, A.; Tonón, C.; Van Damme, M.; Huarte, M.; Daleo, G. Effect of glucans from different races of Phytophthora infestans on defense reactions in potato tuber. Eur. J. Plant Pathol. 1998, 104, 777-783. [CrossRef]

41. Liu, H.; Wang, X.; Zhang, H.; Yang, Y.; Ge, X.; Song, F. A rice serine carboxypeptidase-like gene OsBISCPL1 is involved in regulation of defense responses against biotic and oxidative stress. Gene 2008, 420, 157-165. [CrossRef] [PubMed]

42. Jashni, M.K.; Mehrabi, R.; Collemare, J.; Mesarich, C.H.; de Wit, P.J. The battle in the apoplast: Further insights into the roles of proteases and their inhibitors in plant-pathogen interactions. Front. Plant Sci. 2015, 6, 584. [CrossRef] [PubMed]

43. Avrova, A.O.; Taleb, N.; Rokka, V.M.; Heilbronn, J.; Campbell, E.; Hein, I.; Gilroy, E.M.; Cardle, L.; Bradshaw, J.E.; Stewart, H.E.; et al. Potato oxysterol binding protein and cathepsin B are rapidly up-regulated in independent defence pathways that distinguish R gene-mediated and field resistances to Phytophthora infestans. Mol. Plant Pathol. 2004, 5, 45-56. [CrossRef] [PubMed]

44. Kim, J.Y.; Park, S.C.; Kim, M.H.; Lim, H.T.; Park, Y.K.; Hahm, K.S. Antimicrobial activity studies on a trypsin-chymotrypsin protease inhibitor obtained from potato. Biochem. Biophys. Res. Commun. 2005, 330, 921-927. [CrossRef] [PubMed]

45. Nelson, A.J.; Doerner, P.W.; Zhu, Q.; Lamb, C.J. Isolation of a monocot 3-hydroxy-3-methylglutaryl coenzyme A reductase gene that is elicitor-inducible. Plant Mol. Biol. 1994, 25, 401-412. [CrossRef] [PubMed]

46. Fernández, M.B.; Pagano, M.R.; Daleo, G.R.; Guevara, M.G. Hydrophobic proteins secreted into the apoplast may contribute to resistance against Phytophthora infestans in potato. Plant Physiol. Biochem. 2012, 60, 59-66. [CrossRef]

47. Roumeliotis, E.; Kloosterman, B.; Oortwijn, M.; Visser, R.G.; Bachem, C.W. The PIN family of proteins in potato and their putative role in tuberization. Front. Plant Sci. 2013, 4, 524. [CrossRef]

48. Torto-Alalibo, T.A.; Tripathy, S.; Smith, B.M.; Arredondo, F.D.; Zhou, L.; Li, H.; Chibucos, M.C.; Qutob, D.; Gijzen, M.; Mao, C.; et al. Expressed sequence tags from Phytophthora sojae reveal genes specific to development and infection. Mol. Plant-Microbe Interact. 2007, 20, 781-793. [CrossRef]

49. Wang, J.; Cheng, Y.; Wu, R.; Jiang, D.; Bai, B.; Tan, D.; Yan, T.; Sun, X.; Zhang, Q.; Wu, Z. Antibacterial Activity of Juglone against Staphylococcus aureus: From Apparent to Proteomic. Int. J. Mol. Sci. 2016, 17, 965. [CrossRef]

50. Eliot, A.C.; Kirsch, J.F. Pyridoxal phosphate enzymes: Mechanistic, structural, and evolutionary considerations. Annu. Rev. Biochem. 2004, 73, 383-415. [CrossRef]

51. Van Damme, M.; Bozkurt, T.O.; Cakir, C.; Schornack, S.; Sklenar, J.; Jones, A.M.; Kamoun, S. The Irish Potato Famine Pathogen Phytophthora infestans Translocates the CRN8 Kinase into Host Plant Cells. PloS Pathog. 2012, 8, E1002875. [CrossRef] [PubMed]

52. Bretz, J.R.; Mock, N.M.; Charity, J.C.; Zeyad, S.; Baker, C.J.; Hutcheson, S.W. A translocated protein tyrosine phosphatase of Pseudomonas syringae pv. tomato DC3000 modulates plant defence response to infection. Mol. Microbiol. 2003, 49, 389-400. [CrossRef] [PubMed] 
53. Underwood, W.; Zhang, S.; He, S.Y. The Pseudomonas syringae type III effector tyrosine phosphatase HopAO1 suppresses innate immunity in Arabidopsis thaliana. Plant J. 2007, 52, 658-672. [CrossRef] [PubMed]

54. Rivas, S.; Rougon-Cardoso, A.; Smoker, M.; Schauser, L.; Yoshioka, H.; Jones, J.D.G. CITRX thioredoxin interacts with the tomato Cf-9 resistance protein and negatively regulates defense. EMBO J. 2004, 23, 2156-2165. [CrossRef] [PubMed]

55. Nekrasov, V.; Ludwig, A.A.; Jones, J.D.G. CITRX thioredoxin is a putative adaptor protein connecting Cf-9 and the ACIK1 protein kinase during the Cf-9/Avr9-induced defense response. Febs Lett. 2006, 580, 4236-4241. [CrossRef] [PubMed]

56. Burra, D.D.; Vetukuri, R.R.; Resjö, S.; Grenville-Briggs, L.J.; Andreasson, E. RNAseq and Proteomics for Analysing Complex Oomycete Plant Interactions. Curr. Issues Mol. Biol. 2016, 19, 73-88. [PubMed]

57. Akino, S.; Takemoto, D.; Hosaka, K. Phytophthora infestans: A review of past and current studies on potato late blight. J. Gen. Plant Pathol. 2014, 80, 24-37. [CrossRef]

58. Shibata, Y.; Kawakita, K.; Takemoto, D. Age-related resistance of Nicotiana benthamiana against hemibiotrophic pathogen Phytophthora infestans requires both ethylene- and salicylic acid-mediated signaling pathways. Mol. Plant Microbe Interact. 2010, 23, 1130-1142. [CrossRef]

59. D’Ovidio, R.; Mattei, B.; Roberti, S.; Bellincampi, D. Polygalacturonases, polygalacturonase-inhibiting proteins and pectic oligomers in plant-pathogen interactions. Biochim. Biophys. Acta 2004, 1696, 237-244. [CrossRef]

60. Diener, A.C.; Ausubel, F.M. Resistance to Fusarium Oxysporum 1, a dominant Arabidopsis disease-resistance gene, is not race specific. Genetics 2005, 171, 305-321. [CrossRef]

61. Brutus, A.; Sicilia, F.; Macone, A.; Cervone, F.; De Lorenzo, G. A domain swap approach reveals a role of the plant wall-associated kinase 1 (WAK1) as a receptor of oligogalacturonides. Proc. Natl. Acad. Sci. USA 2010, 107, 9452-9457. [CrossRef] [PubMed]

62. Boller, T.; Felix, G. A Renaissance of Elicitors: Perception of microbe-associated molecular patterns and danger signals by pattern-recognition receptors. Annu. Rev. Plant Biol. 2009, 60, 379-407. [CrossRef] [PubMed]

63. Le Berre, J.Y.; Engler, G.; Panabières, F. Exploration of the late stages of the tomato-Phytophthora parasitica interactions through histological analysis and generation of expressed sequence tags. New Phytol. 2008, 177, 480-492. [CrossRef] [PubMed]

64. Takemoto, D.; Furuse, K.; Doke, N.; Kawakita, K. Identification of Chitinase and Osmotin-Like Protein as Actin-Binding Proteins in Suspension-Cultured Potato Cells. Plant Cell Physiol. 1997, 38, 441-448. [CrossRef]

65. Vleeshouwers, V.G.A.A.; Dooijeweert, W.V.; Govers, F.; Kamoun, S.; TColona, L.T. Does basal PR gene expression in Solanum species contribute to non-specific resistance to Phytophthora infestans? Physiol. Mol. Plant Pathol. 2000, 57, 35-42. [CrossRef]

66. Draffehn, A.M.; Li, L.; Krezdorn, N.; Ding, J.; Lübeck, J.; Strahwald, J.; Muktar, M.S.; Walkemeier, B.; Rotter, B.; Gebhardt, C. Comparative transcript profiling by SuperSAGE identifies novel candidate genes for controlling potato quantitative resistance to late blight not compromised by late maturity. Front. Plant Sci. 2013, 4, 423. [CrossRef]

67. Mosquera, T.; Alvarez, M.F.; Jiménez-Gómez, J.M.; Muktar, M.S.; Paulo, M.J.; Steinemann, S.; Li, J.; Draffehn, A.; Hofmann, A.; Lübeck, J.; et al. Targeted and Untargeted Approaches Unravel Novel Candidate Genes and Diagnostic SNPs for Quantitative Resistance of the Potato (Solanum tuberosum L.) to Phytophthora infestans Causing the Late Blight Disease. PLoS ONE 2016, 11, E0156254. [CrossRef]

68. Bass, S.; Gu, Q.; Christen, A. Multicopy suppressors of prc mutant Escherichia coli include two HtrA (DegP) protease homologs (HhoAB), DksA, and a truncated R1pA. J. Bacteriol. 1996, 178, 1154-1161. [CrossRef]

69. Whisson, S.C.; Boevink, P.C.; Wang, S.; Birch, P.R.J. The cell biology of late blight disease. Curr. Opin. Microbiol. 2016, 34, 127-135. [CrossRef]

70. Meng, Y.; Zhang, Q.; Zhang, M.; Gu, B.; Huang, G.; Wang, Q.; Shan, W. The protein disulfide isomerase 1 of Phytophthora parasitica (PpPDI) is associated with the haustoria-like structures and contributes to plant infection. Front. Plant Sci. 2015, 6, 632. [CrossRef]

71. Oliveira, A.E.; Gomes, V.M.; Sales, M.P.; Fernandes, K.V.; Carlini, C.R.; Xavier-Filho, J. The toxicity of jack bean [Canavalia ensiformis (L.) DC.] canatoxin to plant pathogenic fungi. Rev. Bras. Biol. 1999, 59, 59-62. [CrossRef] 
72. Becker-Ritta, A.B.; Martinelli, H.S.; Mitidieri, S.; Feder, V.; Wassermann, G.E.; Santi, L.; Vainstein, M.H.; Oliveira, J.T.A.; Fiuza, L.M.; Pasquali, G.; et al. Antifungal activity of plant and bacterial ureases. Toxicon 2007, 50, 971-983. [CrossRef] [PubMed]

73. Resjö, S.; Brus, M.; Ali, A.; Meijer, H.J.G.; Sandin, M.; Govers, F.; Levander, F.; Grenville-Briggs, L.; Andreasson, E. Proteomic Analysis of Phytophthora infestans Reveals the Importance of Cell Wall Proteins in Pathogenicity. Mol. Cell Proteom. 2017, 16, 1958-1971. [CrossRef] [PubMed]

74. Tanimura, A.; Kondo, Y.; Tanaka, H.; Matsumura, I.; Ishibashi, T.; Sudo, T.; Satoh, Y.; Yokota, T.; Ezoe, S.; Oritani, K.; et al. An Anti-Apoptotic Molecule, Anamorsin, Functions in Both Iron-Sulfur Protein Assembly and Cellular Iron Homeostasis. Blood 2011, 118, 2106.

75. Gyetvai, G.; Sonderkaer, M.; Gobel, U.; Basekow, R.; Ballvora, A.; Imhoff, M.; Kersten, B.; Kare-Lehman Nielsen, K.L.; Gebhardt, C. The Transcriptome of Compatible and Incompatible Interactions of Potato (Solanum tuberosum) with Phytophthora infestans Revealed by DeepSAGE Analysis. PLoS ONE 2012, 7, E31526. [CrossRef] [PubMed]

76. Chen, L.; Huang, Y.; Xu, M.; Cheng, Z.; Zhang, D.; Zheng, J. iTRAQ-Based Quantitative Proteomics Analysis of Black Rice Grain Development Reveals Metabolic Pathways Associated with Anthocyanin Biosynthesis. PLOS ONE 2016, 7, e0159238. [CrossRef] [PubMed]

77. Liu, Y.; Hüttenhain, R.; Collins, B.; Aebersold, R. Mass spectrometric protein maps for biomarker discovery and clinical research. Expert Rev. Mol. Diagn. 2013, 13, 811-825. [CrossRef] [PubMed]

78. Vizcaino, J.A.; Csordas, A.; Del-Toro, N.; Dianes, J.A.; Griss, J.; Lavidas, I.; Mayer, G.; Perez-Riverol, Y.; Reisinger, F.; Ternent, T.; et al. 2016 update of the PRIDE database and its related tools. Nucleic Acids Res. 2015, 44, D447-D456. [CrossRef]

79. Consortium TGO. Gene Ontology Consortium: Going forward. Nucleic Acids Res. 2015, 43, D1049-D1056. [CrossRef]

80. Conesa, A.; Götz, S. Blast2GO: A Comprehensive Suite for Functional Analysis in Plant Genomics. Int. J. Plant Genom. 2008, 2008, 619832. [CrossRef]

81. Kanehisa, M.; Furumichi, M.; Tanabe, M.; Sato, Y.; Morishima, K. KEGG: New perspectives on genomes, pathways, diseases, and drugs. Nucleic Acids Res. 2017, 45, D353-D361. [CrossRef] [PubMed]

82. Smoot, M.E.; Ono, K.; Ruscheinski, J.; Wang, P.L.; Ideker, T. Cytoscape 2.8: New features for data integration and network visualization. Bioinformatics 2010, 27, 431-432. [CrossRef] [PubMed]

83. Pang, C.Y.; Wang, H.; Pang, Y.; Xu, C.; Jiao, Y.; Qin, Y.M.; Western, T.L.; Yu, S.X.; Zhu, Y.X. Comparative proteomics indicates that biosynthesis of pectic precursors is important for cotton fiber and Arabidopsis root hair elongation. Mol. Cell Proteom. 2010, 9, 2019-2033. [CrossRef] [PubMed]

84. Xie, C.; Mao, X.; Huang, J.; Ding, Y.; Wu, J.; Dong, S.; Kong, L.; Gao, G.; Li, C.Y.; Wei, L. KOBAS 2.0: A web server for annotation and identification of enriched pathways and diseases. Nucleic Acids Res. 2011, 39, 316-322. [CrossRef] [PubMed]

85. Howden, A.J.M.; Stam, R.; Heredia, V.M.; Motion, G.B.; Have, S.T.; Hodge, K.; Amaro, T.M.M.M.; Huitema, E. Quantitative Analysis of the Tomato Nuclear Proteome during Phytophthora Capsici Infection Unveils Regulators of Immunity. New Phytol. 2017, 215, 309-322. [CrossRef] [PubMed]

86. Aldridge, G.M.; Podrebarac, D.M.; Greenough, W.T.; Weiler, I.J. The Use of Total Protein Stains as Loading Controls: An Alternative to High-Abundance Single-Protein Controls in Semi-Quantitative Immunoblotting. J. Neurosci. Methods 2008, 172, 250-254. [CrossRef] [PubMed]

87. Livak, K.J.; Schmittgen, T.D. Analysis of relative gene expression data using real-time quantitative PCR and the $2^{-\Delta \Delta C T}$ method. Methods 2001, 25, 402-408. [CrossRef]

(C) 2019 by the authors. Licensee MDPI, Basel, Switzerland. This article is an open access article distributed under the terms and conditions of the Creative Commons Attribution (CC BY) license (http://creativecommons.org/licenses/by/4.0/). 